\title{
Dyslipidemia aterogenna w codziennej praktyce - interdyscyplinarny konsensus polskich ekspertów
}

\author{
Atherogenic dyslipidemia in everyday practice \\ - interdisciplinary consensus of Polish experts
}

Filip M. Szymański ${ }^{1}$, Krzysztof J. Filipiak ${ }^{1}$, Beata Wożakowska-Kapłon ${ }^{2}$, Jacek P. Szaflik ${ }^{3}$, Grzegorz Dzida ${ }^{4}$, Iwona Kurkowska-Jastrzębska ${ }^{5}$, Krzysztof Narkiewicz ${ }^{6}$, Monika Łazicka-Gałecka ${ }^{3}$, Robert J. Gil ${ }^{7}$, Janusz Gumprecht ${ }^{8}$

${ }^{1}$ I Katedra i Klinika Kardiologii Warszawskiego Uniwersytetu Medycznego

${ }^{2}$ I Klinika Kardiologii i Elektroterapii Świętokrzyskiego Centrum Kardiologii w Kielcach

${ }^{3}$ Katedra i Klinika Okulistyki Warszawskiego Uniwersytetu Medycznego

${ }^{4}$ Katedra i Klinika Chorób Wewnętrznych Uniwersytetu Medycznego w Lublinie

${ }^{5}$ II Klinika Neurologiczna Instytutu Psychiatrii i Neurologii w Warszawie

${ }^{6}$ Klinika Nadciśnienia Tętniczego i Diabetologii Gdańskiego Uniwersytetu Medycznego

${ }^{7}$ Klinika Kardiologii Inwazyjnej Centralnego Szpitala Klinicznego Ministerstwa Spraw Wewnętrznych i Administracji w Warszawie

${ }^{8}$ Klinika Chorób Wewnętrznych, Diabetologii i Nefrologii Śląskiego Uniwersytetu Medycznego w Zabrzu

\section{Streszczenie}

Zaburzenia lipidowe są najbardziej rozpowszechnionym czynnikiem ryzyka chorób układu sercowo-naczyniowego w Polsce. Według najnowszych wytycznych towarzystw naukowych nadrzędnym celem terapii hipolipemizującej jest obniżenie stężenia cholesterolu frakcji LDL, niemniej jednak nie można nie doceniać wpływu, jaki na postęp zmian miażdżycowych w naczyniach tętniczych wywiera aterogenna dyslipidemia, czyli podwyższone stężenie triglicerydów (TG) i lipoprotein o bardzo małej gęstości (VLDL) zawierających TG oraz obniżone stężenie frakcji cholesterolu HDL (HDL-C). Wysokie stężenie TG i niskie stężenie HDL-C są niezależnymi czynnikami ryzyka zdarzeń sercowo-naczyniowych, które można skutecznie kontrolować i leczyć za pomocą statyn i fenofibratu. Poniższe stanowisko polskich ekspertów wielu dziedzin stanowi próbę podsumowania najnowszej wiedzy w dziedzinie dyslipidemii aterogennej i sformułowanie zaleceń dotyczących jej leczenia.

Słowa kluczowe: aterogenna dyslipidemia, stanowisko ekspertów, ryzyko sercowo-naczyniowe

Folia Cardiologica 2017; 12, 1: 33-49

\section{Wstęp}

Zaburzenia lipidowe są najbardziej rozpowszechnionym czynnikiem ryzyka chorób sercowo-naczyniowych w Polsce. Nadrzędnym celem terapii hipolipemizującej jest obniżenie cholesterolu frakcji LDL (LDL-C, low-density lipoprotein cholesterol). Nie można jednak nie doceniać wpływu, jaki na postęp zmian miażdżycowych w naczyniach tętniczych wywiera aterogenna dyslipidemia. Waga problemu aterogennej dyslipidemii jest niestety niedoceniana. Zaburzenie jest zbyt rzadko rozpoznawane i poddawane prawidłowej terapii. Zrozumienie patologii związanych

Adres do korespondencji: dr hab. n. med. Filip M. Szymański, I Katedra i Klinika Kardiologii, Warszawski Uniwersytet Medyczny, ul. Banacha 1a, 02-097 Warszawa, tel. 2259919 58, faks 2259919 57, e-mail: filip.szymanski@wum.edu.pl 
z tym rodzajem dyslipidemii wymaga uwagi, dalszych obserwacji i badań, a także wdrożenia adekwatnego postępowania leczniczego. Ze względu na szeroki zakres występowania tej patologii w Polsce i wielodyscyplinarność problemu obejmującego wpływ aterogennej dyslipidemii na powikłania makro- i mikronaczyniowe w niniejszym artykule zaprezentowano stanowisko interdyscyplinarne polskich ekspertów. Celem prezentowanego stanowiska jest holistyczne spojrzenie na jednostkę chorobową, jaką jest dyslipidemia aterogenna.

\section{Definicja}

Aterogenna dyslipidemia definiowana jest jako podwyzszone stężenie triglicerydów (TG) wynoszące $150 \mathrm{mg} / \mathrm{dl}$ ( 1,7 mmol/l) lub wyższe, lipoprotein o bardzo małej gęstości (VLDL, very-low-density lipoprotein) zawierających TG oraz obniżone stężenie frakcji HDL cholesterolu (HDL-C, high-density lipoprotein cholesterol): u mężczyzn poniżej $40 \mathrm{mg} / \mathrm{dl}$ ( 1 mmol/l), u kobiet poniżej $45 \mathrm{mg} / \mathrm{dl}$ $(\sim 1,2 \mathrm{mmol} / \mathrm{I})$ [1, 2]. Stężenie LDL-C bywa u chorych z aterogenną dyslipidemią prawidłowe bądź podwyższone. Cząsteczki LDL-C są w tym przypadku mniejsze, charakteryzują je większa gęstość i większy potencjał aterogenności między innymi ze względu na zwiększoną zawartość apolipoproteiny B (apo B). W europejsko-kanadyjskim rejestrze Dyslipidemia International Study, obejmującym 22063 osób leczonych w warunkach ambulatoryjnych statyną, wykazano, że w obserwowanej grupie występowało podwyższone stężenie TG i/lub obniżone stężenie HDL-C [3]. W polskiej populacji stężenie HDL-C poniżej $40 \mathrm{mg} / \mathrm{dl}$ obserwuje się u 35\% mężczyzn, a mniejsze niż $50 \mathrm{mg} / \mathrm{dl}$ u 38\% kobiet. Hipertriglicerydemia (TG $\geq 150 \mathrm{mg} / \mathrm{dl}$ ) występuje u 22\% badanych (u 28\% mężczyzn i u 14\% kobiet). Jeżeli za próg hipertriglicerydemii przyjąć TG wynoszące co najmniej $200 \mathrm{mg} /$ dl, dotyczy ona blisko 11\% dorosłych Polaków [4]. Wspominane dane z badania NATPOL 2011 pozwalają szacować, że 10,5 miliona dorosłych Polaków na obniżone stężenie HDL-cholesterolu, a 3,2 mln na stężenie TG wynoszące $200 \mathrm{mg} / \mathrm{dl}$ lub wyższe.

Dyslipidemia aterogenna jest szczególnie istotna w grupie pacjentów z nadciśnieniem tętniczym. W dużym rejestrze europejskim [5] wykazano, że aż $22 \%$ chorych z NT ma niskie stężenie cholesterolu HDL, u 30\% pacjentów wartości TG wynoszą powyżej $150 \mathrm{mg} / \mathrm{dl}$, a u 11\% występują obie nieprawidłowości. Chorzy z dyslipidemią aterogenną mają częściej subkliniczne zmiany narządowe (przerost lewej komory serca, obniżony szacunkowy współczynnik filtracji kłębuszkowej [eGFR, estimated glomerular filtration rate] $<60 \mathrm{ml} / \mathrm{min}$ i mikroalbuminuria), częściej występuje u nich brak spadku wartości ciśnienia tętniczego w godzinach nocnych. Wymagają stosowania większej liczby leków hipotensyjnych, a kontrola wartości ciśnienia tętniczego jest u nich słabsza. W grupie chorych z dyslipidemią aterogenną tylko 7,6\% otrzymywało fibraty (w tym u 1,5\% stosowano leczenie skojarzone fibrat/statyna). Wszystko to spowodowało, że w zaleceniach Polskiego Towarzystwa Nadciśnienia Tętniczego (PTNT), Europejskiego Towarzystwa Kardiologicznego (ESC, European Society of Cardiology) oraz Europejskiego Towarzystwa Nadciśnienia Tętniczego (ESH, European Society of Hypertension) podwyższone stężenie TG określono jako niezależny czynnik ryzyka.

\section{Zaburzenia lipidowe w aterogennej dyslipidemii}

Aterogenną dyslipidemię charakteryzuje nadmiar kwasów tłuszczowych i TG we krwi oraz w wątrobie. Za tę anomalię odpowiadają dysfunkcje różnych szlaków metabolicznych. Wydaje się, że najważniejsze z nich to: nasilenie lipolizy w tkance tłuszczowej, zwiększenie lipogenezy de novo z glukozy regulowane przez insulinę oraz zmniejszenie oksydacji kwasów tłuszczowych. W przypadku oporności na insulinę, u osób z otyłością brzuszną, zespołem metabolicznym, u chorych na cukrzycę insulinoniezależną nie zachodzi tłumienie lipolizy indukowane przez insulinę. Lipoproteiny bogate w TG po ich uwolnieniu z wątroby lub jelita ulegają hydrolizie katalizowanej przez lipazę lipoproteinową, co prowadzi do powstania lipoprotein resztkowych bogatych w cholesterol. Cząsteczki te są zdolne do przenikania przez błonę wewnętrzną tętnic, następnie są wychwytywane przez makrofagi i zapoczątkowują proces powstawania komórek piankowatych. Nasilenie napływu wolnych kwasów tłuszczowych z towarzyszącą syntezą dużych cząstek VLDL stanowi podstawową nieprawidłowość obserwowaną w aterogennej dyslipidemii-można je zaliczyć do jednej z trzech składowych triady aterogennej [6].

Kolejna nieprawidłowość obserwowana u osób z aterogenną dyslipidemią związana jest $z$ działaniem białka przenoszącego estry cholesterolu (CETP, cholesteryl ester transfer protein). Białko CETP pośredniczy w transporcie estrów cholesterolu między lipoproteinami o bardzo małej, pośredniej i małej gęstości (VLDL, lipoproteiny o pośredniej gęstości [IDL, intermediate-density lipoprotein] i LDL) a lipoproteinami o dużej gęstości (HDL). Cholesterol frakcji HDL to zbiór dynamicznie zmieniających się cząstek uczestniczących w zwrotnym transporcie cholesterolu. Białko CETP bierze udział w procesie remodelingu cząstek HDL oraz umożliwia powrót zestryfikowanego cholesterolu odebranego przez cząsteczki HDL z tkanek i krwioobiegu. Kluczowym zadaniem HDL jest usuwanie nadmiaru cholesterolu z tkanek obwodowych. Zmniejszone stężenie HDL-C oraz powstawanie małych, gęstych, aterogennych cząstek LDL-C są kolejnymi składowymi klasycznej lipidowej triady aterogennej. Duży potencjał aterogenny małych, gęstych 
LDL-C w aterogennej dyslipidemii wiąże się z dużą zawartością apo B w tych cząsteczkach [7].

\section{Oznaczanie cholesterolu nie-HDL}

Sumę aterogennych cząsteczek w osoczu tworzą cząsteczki VLDL, IDL oraz LDL-C. Ich stężenie można obliczyć, odejmując od stężenia cholesterolu całkowitego stężenie HDL-C. Otrzymuje się wówczas stężenie cholesterolu nie-HDL (nie-HDL-C), który bardzo dobrze odzwierciedla ryzyko sercowo-naczyniowe, ponieważ stężenie to dobrze koreluje ze stężeniem apo-B, a więc potencjałem promiażdżycowym [7]. Ocena nie-HDL-C jest bardzo prosta i szczególnie istotna u chorych $z$ hipertriglicerydemią związaną z cukrzycą, zespołem metabolicznym, otyłością brzuszną, przewlekłą chorobą nerek. Zalety obliczania stężenia nie-HDL-C są następujące: do oznaczenia tego parametru nie jest konieczne wykonywanie badania na czczo oraz pomiar można przeprowadzić przy wysokim stężeniu TG [1, 2, 7]. W 2016 roku ESC doceniło stężenie nie-HDL-C, uznając je w najnowszych zaleceniach terapii dyslipidemii za jedyny cel drugorzędowy leczenia (cel pierwszorzędowy to obniżenie stężenia LDL-C).

Wartości docelowe określone dla nie-HDL-C powinny być o $30 \mathrm{mg} / \mathrm{dl}$ wyższe $(\sim 0,8 \mathrm{mmol} / \mathrm{l})$ niż odpowiadające im wartości docelowe LDL-C, odpowiada to stężeniu LDL-C powiększonemu o frakcję cholesterolu zawartą w $150 \mathrm{mg} / \mathrm{dl}$ TG, czyli górnej granicy zalecanych wartości TG [1]. Uzyskanie optymalnego stężenia nie-HDL-C jest głównym celem w przypadku resztkowego ryzyka incydentów sercowo-naczyniowych (ryzyka rezydualnego, inaczej ryzyka po osiągnięciu optymalnego LDL-C; patrz dalej). Nowe wytyczne europejskie dotyczące dyslipidemii za cel pierwszorzędowy określają osiągnięcie stężenia LDL-C: poniżej $70 \mathrm{mg} / \mathrm{dl}$ lub mniejszego, poniżej $100 \mathrm{mg} / \mathrm{dl}$ lub mniejszego oraz poniżej $115 \mathrm{mg} / \mathrm{dl}$ odpowiednio u osób: bardzo wysokiego, wysokiego oraz średniego i niskiego ryzyka sercowo-naczyniowego. Te same wytyczne za cel drugorzędowy uznają osiągnięcie nie-HDL-C: mniejsze niż $100 \mathrm{mg} / \mathrm{dl}$, mniejsze niż $130 \mathrm{mg} / \mathrm{dl}$ oraz mniejsze niż $145 \mathrm{mg} / \mathrm{dl}$ odpowiednio dla osób: bardzo wysokiego, wysokiego oraz średniego ryzyka sercowo-naczyniowego.

W jednej z dotychczasowych metaanaliz, obejmującej 8 dużych badań: 4S (Scandinavian Simvastatin Survival Study), AFCAPS-TexCAPS (Air Force/Texas Coronary Atherosclerosis Prevention Study), LIPID (Long-term Intervention with Pravastatin in Ischemic Disease Study), CARDS (Collaborative Atorvastatin Diabetes Study), TNT (Treating to New Targets), IDEAL (Incremental Decrease in End Points through Aggressive Lipid Lowering), SPARCL (Stroke Prevention by Aggressive Reduction in Cholesterol Levels), JUPITER (Justification for the Use of Statins in Primary Prevention: an Intervention Trial Evaluating Rosuvastatin), w których brało udział 62154 pacjentów, wykazano, że stężenie takich parametrów lipidowych, jak LDL-C, nie-HDL-C, apoB, było powiązane z ryzykiem sercowo-naczyniowym w statystycznie istotny sposób. Zależność ta była jednak najsilniejsza dla nie-HDL-C (ryzyko względne [HR, hazard ratio] 1,42, 95-proc. przedział ufności [Cl, confidence interval] 1,2-1,56) oraz apo B (HR 1,33, 95\% Cl 1,22-1,45) [8]. W analizie wykazano, że różnica między LDL-C a nie-HDL-C w prognozowaniu ryzyka wystąpienia zdarzeń sercowo-naczyniowych jest znamienna statystycznie $(p=0,002)$ na korzyść nie-HDL-C jako silniejszego markera. Co więcej, można przyjąć, że prymat „celu pierwszorzędowego” (LDL-C) nad „celem drugorzędowym” (nie-HDL-C) wynika przede wszystkim z ogromu badań statynowych i dowodów na korzyści obniżania LDL-C. Dotychczas nie przeprowadzono badań na taką skalę dla nie-HDL-C.

Boekholdt i wsp. [8] dokonali metaanalizy w celu przybliżenia związku między stężeniami cholesterolu LDL, nie-HDL i apoB a ryzykiem wystąpienia zdarzeń sercowo-naczyniowych wśród pacjentów leczonych statynami. Efekt leczenia (statyna v. placebo lub duża dawka statyny v. średnia dawka) w odniesieniu do ryzyka zdarzeń sercowo-naczyniowych był uwarunkowany wpływem interwencji na parametry lipidowe. Wywołane statynami zmiany w stężeniach LDL-C tłumaczą około 50\% efektów wywołanych leczeniem, podczas gdy wpływ statyn na stężenie nie-HDL-C wyjaśnia $64 \%$ efektów. Należy zauważyć, że wśród osób przyjmujących statynę cholesterol nie-HDL był silniej związany prognostycznie z ryzykiem wystąpienia poważnego epizodu sercowo-naczyniowego niż cholesterol LDL i apoB [8]. Być może te właśnie dane spowodowały, że w nowych wytycznych europejskich dotyczących dyslipidemii z 2016 roku można zaobserwować przyznanie większego znaczenia cholesterolowi nie-HDL (podniesienie go do pozycji „celu drugorzędowego") i pewne zmniejszenie wagi oznaczania stężeń apoB.

\section{Znaczenie kliniczne \\ aterogennej dyslipidemii, pojęcie rezydualnego ryzyka makronaczyniowego}

Mimo stosowania schematów postępowania zgodnych z obowiązującymi standardami i pozwalających osiągnąc docelowe stężenia LDL-C, łącznie z intensywną kontrolą ciśnienia tętniczego i glikemii, u pacjentów $z$ aterogenną dyslipidemią, zwłaszcza u chorych na cukrzycę i z zespołem metabolicznym, ryzyko powikłań mikronaczyniowych (neuropatii, retinopatii i nefropatii) oraz makronaczyniowych (zawału serca, udaru mózgu, choroby naczyń obwodowych, zgonu sercowego) nadal pozostaje duże. To szczątkowe ryzyko obciążające chorych, stwierdzane mimo osiągania docelowych wartości LDL-C, nazwano ryzykiem rezydualnym (wg bardziej wymagającej definicji 
ryzyko rezydulane pozostaje mimo optymalnego stężenia LDL-C, glikemii i normotonii). Skoncentrowanie się jedynie na zmniejszeniu stężenia LDL-C nie wpływa na ryzyko rezydualne związane z niskim stężeniem HDL-C i wysokim stężeniem TG. Chorzy z niskim stężeniem HDL-C narażeni są zatem na nasilenie zmian oksydacyjnych, zapalnych agregacyjnych i protrombogennych, co sprzyja rozwojowi miażdżycy, mimo że samo stężenie HDL-C nie jest aktualnie celem leczenia.

W przeprowadzonej przez Hokansona i Austina [9] metaanalizie 17 badań, obejmujących 57277 osób, stwierdzono, że wzrost stężenia TG o $1 \mathrm{mmol} / \mathrm{l}$ był związany ze zwiększeniem ryzyka choroby wieńcowej o 30\% u mężczyzn i o 75\% u kobiet. W wynikach badań PROVE-IT TIMI 22 (Pravastatin or Atorvastatin Evaluation and Infection Therapy-Thrombolysis In Myocardial Infarction), PROCAM (Prospective Cardiovascular Münster), ACCORD Lipid (Action to Control Cardiovascular Risk in Diabetes Lipid Trial), IDEAL i TNT wykazano, że podwyższone stężenie TG oraz niskie stężenie HDL-C wiążą się z wyższym ryzykiem zgonów i zdarzeń sercowo-naczyniowych [10-12]. W badaniach udowodniono związek aterogennej dyslipidemii z ryzykiem rezydualnym incydentów sercowo-naczyniowych u chorych leczonych statyną. W subanalizie badania TNT wykazano, że mimo dostatecznie niskich stężeń LDL-C $(<70 \mathrm{mg} / \mathrm{dl})$ istotne znaczenie dla rokowania miało stężenie HDL-C, zmodyfikowano je w 5-letniej perspektywie nawet o 39\% u chorych ze stężeniem HDL-C co najmniej $55 \mathrm{mg} / \mathrm{dl}[13]$.

U pacjentów z dyslipidemią aterogenną występuje większe ryzyko wystąpienia makulopatii, pojawienia się i progresji retinopatii cukrzycowej. Stwierdzono również związek aterogennej dyslipidemii z występowaniem albuminurii i nefropatii cukrzycowej. $U$ chorych na cukrzyce typu 2 wykazano, że wysokie stężenie TG ma niezależny wpływ na rozwój mikroalbuminurii i makroalbuminurii, a także uszkodzenia nerwów obwodowych [14, 15]. Neuropatii obwodowej często towarzyszy inne poważne powikłanie - rozwój zespołu stopy cukrzycowej. Wykazanie wspomnianych zależności uzasadnia konieczność kontroli profilu lipidowego u osób $z$ aterogenną dyslipidemią, zwłaszcza u chorych na cukrzycę i z zespołem metabolicznym.

Redukcja ryzyka rezydualnego zwłaszcza u pacjentów $z$ aterogenną dyslipidemią stała się celem programu 3R (Residual Risk Reduction Initiative). Ta globalna inicjatywa jest naukowym przedsięwzięciem non-profit mającym na celu badanie wpływu aterogennej dyslipidemii na powikłania mikro- i makronaczyniowe występujące mimo prowadzonej standardowej opieki medycznej.
Jak można wpływać na ryzyko rezydualne?

Redukcja powikłań makronaczyniowych w wybranych badaniach

\section{z zastosowaniem fibratów}

Fundamentalnym badaniem, w którym wykazano istotne korzyści kliniczne z korekcji zaburzeń lipidowych towarzyszących aterogennej dyslipidemii, było badanie ACCORD Lipid [16]. Tę trwającą 5 lat próbę kliniczną przeprowadzono w grupie 5518 chorych na cukrzycę typu 2, u których strategię monoterapii statyną (simwastatyna $n=2753$ ) porównywano z terapią kompleksową statyną z fenofibratem ( $n=2765)$. Dawka początkowa fenofibratu wynosiła 160 mg, modyfikowano ją w zależności od filtracji kłębuszkowej obliczanej według wzoru modyfikacji diety u chorych z nefropatią (MDRD, modification of diet in renal disease). Pierwszorzędowy złożony punkt końcowy badania obejmował zawał serca, udar mózgu i zgon sercowo-naczyniowy, drugorzędowy punkt końcowy zaś inne zdarzenia sercowo-naczyniowe (rewaskularyzacja, hospitalizacja z powodu niewydolności serca lub pierwszorzędowy punkt końcowy), śmiertelność całkowitą, główne zdarzenia w stabilnej chorobie wieńcowej, udary zakończone i niezakończone zgonem, zgony i hospitalizacje w stabilnej chorobie wieńcowej, incydenty niewydolności serca zakończone i niezakończone zgonem [17]. W obu badanych grupach zarówno pierwszorzędowy punkt końcowy, jak i drugorzędowy wystąpiły z podobną częstotliwością, natomiast po zdefiniowaniu grupy pacjentów z wysokim stężeniem TG co najmniej $204 \mathrm{mg} / \mathrm{dl}$ oraz niskim stężeniem HDL-C nie większym niż $34 \mathrm{mg} / \mathrm{dl}$ wykazano korzyści z terapii fibratem w tej grupie chorych. Stwierdzono, że dodanie fibratu do statyny prowadziło do redukcji pierwotnego złożonego punktu końcowego o 31\% [17]. Badanie ACCORD było pierwszym badaniem prospektywnym porównującym terapię statyną i fenofibratem z monoterapią statyną. W badaniu ACCORD Lipid wykazano ponadto, że incydenty sercowo-naczyniowe (zgon, zawał serca, udar mózgu) występowały $70 \%$ częściej w grupie aterogennej dyslipidemii w porównaniu z osobami bez aterogennej dyslipidemii). Dodanie fenofibratu do simwastatyny istotnie zmniejszało ryzyko rezydualne związane z podwyższonym stężeniem TG i niskim stężeniem HDL-C. Korzystny wpływ terapii fibratem w opisywanym badaniu wykazano również w odniesieniu do redukcji mikro- i makroalbuminurii [17]. Korzyści z terapii fibratami związane z redukcją powikłań makro- i mikronaczyniowych potwierdzono w innych badaniach klinicznych [18-20].

Badaniem, w którym wskazano na korzystny wpływ terapii fibratem na redukcję incydentów makronaczy- 
niowych (redukcja zgonów i ryzyko incydentów sercowo-naczyniowych) u pacjentów na chorobę niedokrwienną serca, było badanie BIP (Bezafibrate Infarction Prevention) [18]. W 18 ośrodkach kardiologicznych w Izraelu włączano do badania chorych $(n=3090)$ po przebytym zawale serca ( $\geq 6$ miesięcy wcześniej, ale nie dawniej niż przed 5 laty) lub ze stabilną dławicą piersiową potwierdzoną badaniem koronarograficznym, scyntygraficznym lub standardową próbą wysiłkową, u których stężenia lipidów w surowicy wynosiły: cholesterol całkowity 180-250 mg/dl (4,66-6,48 mmol/l), LDL-C nie większy niż $180 \mathrm{mg} / \mathrm{dl}(\leq 4,66 \mathrm{mmol} / \mathrm{I}$ ) (u chorych $<50$ lat $\leq 160 \mathrm{mg} / \mathrm{dl}[\leq 4,14 \mathrm{mmol} / \mathrm{l}])$, HDL-C nie większy niż $45 \mathrm{mg} / \mathrm{dl}(1,17 \mathrm{mmol} / \mathrm{l})$, TG nie większy niż $300 \mathrm{mg} / \mathrm{dl}$ (<3,4 mmol/l). Kryteria wykluczające z badania były następujące: cukrzyca typu 1, ciężka niewydolność serca, niestabilna dławica piersiowa, niewydolność nerek lub wątroby, nadwrażliwość na bezafibrat, przyjmowanie innych leków hipolipemizujących. W grupie aktywnie leczonej oprócz interwencji dietetycznej chorzy otrzymywali bezafibrat (preparat o przedłużonym uwalnianiu) $400 \mathrm{mg}$ raz/dobę (średnio w ciągu 6,2 roku), w drugiej grupie chorzy otrzymywali placebo. Badanie wykonywane było w ostatniej dekadzie ubiegłego stulecia, dlatego możliwy był schemat badania bez zastosowania statyny w opisanej grupie chorych. Pierwszorzędowy punkt końcowy stanowił zawał serca (zakończony zgonem bądź nie) lub nagły zgon; dodatkowe punkty końcowe to: hospitalizacja z powodu niestabilnej dławicy piersiowej, potrzeba wykonania przezskórnej angioplastyki wieńcowej lub wszczepienia pomostów aortalno-wieńcowych, zgon z jakiejkolwiek przyczyny, udar mózgu. W analizie post hoc (zaplanowanej po zakończeniu badania), obejmującej jedynie osoby z wyjściowym stężeniem TG mniejszym niż 200 mg/dl (2,26 mmol/I), nie stwierdzono korzyści z terapii fibratem, natomiast u osób ze stężeniem TG co najmniej 200 mg/dl (2,26 mmol/l) leczenie bezafibratem wiązało się ze znamiennym zmniejszeniem ryzyka wystąpienia głównego punktu końcowego (12\% v. 19,7\%, względna redukcja ryzyka [RRR, relative risk reduction] 39,5\%; $p=0,02$ ) [18]. Bardzo interesujących danych dostarcza 20-letnia obserwacja kohorty pacjentów z badania BIP przeprowadzona przez Arbela i wsp. [19]. Otóż mimo zaprzestania przyjmowania leku u pacjentów w grupie „fibratowej” obserwowano istotną redukcję o 10\% umieralności w 20-letniej obserwacji. Wyższą, bo o $25 \%$, redukcję obserwowano w grupie, która wyjściowo prezentowała podwyższone stężenie TG i przyjmowała fibrat. Wyniki te wskazują, że korzystne skutki terapii fibratem u pacjentów z choroba niedokrwienną serca i hipertriglicerydemią utrzymują się również po okresie aktywnego leczenia [19].

\section{Redukcja powikłań mikronaczyniowych} w badaniach z zastosowaniem fibratów $U$ chorych z aterogenną dyslipidemią mimo osiągania celu leczenia w postaci redukcji stężenia do wartości docelowych LDL-C, nadal pozostaje duże ryzyko powikłań mikronaczyniowych - retinopatii, nefropatii i neuropatii. Chorzy w podwyższonym stężeniem TG i LDL-C są częściej narażeni na rozwój makulopatii cukrzycowej. Podwyższone stężenie TG jest czynnikiem ryzyka retinopatii proliferacyjnej, a stopień jej zaawansowania jest proporcjonalny do stężenia TG i odwrotnie proporcjonalny do stężenia HDL-C [20]. Podwyższone stężenie TG wiąże się z rozwojem albuminurii, swoistego markera nefropatii, niezależnie od progresji albuminurii wywołanej cukrzycą. Niskie stężenie HDL-C i podwyższone stężenie TG na czczo są odpowiedzialne za rozwój neuropatii obwodowej. Istnieją dowody z badań klinicznych, że stosowanie fibratów istotnie zmniejsza ryzyko powikłań mikronaczyniowych u chorych na cukrzyce. W badaniu FIELD (Fenofibrate and intervention and Event Lowering in Diabetes) u pacjentów chorych na cukrzycę poddawanych terapii fenofibratem stwierdzano istotnie mniejszą częstość progresji do mikroalbuminurii bądź z mikro- do makroalbuminurii w porównaniu z grupą otrzymującą placebo [21]. W grupie leczonej fibratem obserwowano również mniejszy odsetek chorych wymagających leczenia retinopatii z zastosowaniem laseroterapii. Ponadto terapia fibratem prowadziła do 36-procentowej redukcji ryzyka amputacji kończyny dolnej w przebiegu cukrzycy. Opisywane korzyści były niezależne od wartości glikemii i stosowania inhibitorów konwertazy angiotensyny [21]. Korzystny wpływ terapii mikronizowanym fenofibratem na przebieg nefropatii cukrzycowej (regresja albuminurii bądź brak progresji) wykazano również w badaniu DAIS (Diabetes Atherosclerosis Intervention Study) [22]. Wspomniane już w kontekście zmian makronaczyniowych badanie ACCORD Lipid dostarczyło także dowodów na zmniejszenie w grupie przyjmującej fibrat zarówno makro-, jak i mikroalbuminurii [17]. Częścią badania ACCORD Lipid było badanie ACCORD EYE służące ocenie wpływu terapii statyną i fibratem na zahamowanie retinopatii cukrzycowej w grupie chorych na cukrzyce typu 2 [23]. Pierwszorzędowy punkt badania stanowiły pogorszenie wzroku, oceniane jako wzrost o 3 stopnie w 17-stopniowej skali rozwoju retinopatii, lub diagnoza retinopatii proliferacyjnej wymagająca fotokoagulacji albo witrektomii. W grupie leczonej fenofibratem po 4 latach obserwacji stwierdzono zmniejszenie tempa rozwoju retinopatii cukrzycowej o 40\%. Korzyści te były niezależne od kontroli glikemii i występowały zarówno w grupie intensywnej, jak i standardowej kontroli glikemii 
[23]. Wyniki badania ACCORD EYE stanowią dowód na pozalipidowe działanie fibratów, potwierdzają obserwacje poczynione uprzednio w badaniu FIELD. Redukcja powikłań mikronaczyniowych przez fibraty związana jest z poprawą funkcji śródbłonka, zmniejszanie gotowości prozakrzepowej zachodzi prawdopodobnie dzięki działaniu na receptory aktywowane przez proliferatory peroksysomów PPAR- $\alpha$ i PPAR- $\gamma$. Uwaga! Fenofibrat nie jest wskazany w Polsce do stosowania w prewencji i leczeniu powikłań mikronaczyniowych, w tym retinopatii.

\section{Fibraty w dobie prymatu}

kardiologii inwazyjnej

Pacjenci po ostrym zespole wieńcowym (ACS, acute coronary syndrome) i osoby z istotnymi czynnościowo zmianami w tętnicach wieńcowych stanowią populację chorych bardzo wysokiego ryzyka. Według wytycznych ESC u takich pacjentów powinno dążyć się do uzyskania stężenia LDL-C równego $70 \mathrm{mg} / \mathrm{dl}$ (1,8 mmol/l) lub niższego, nie-HDL-C zaś - poniżej $100 \mathrm{mg} / \mathrm{dl}$. W tym miejscu warto zaznaczyć, że oznaczenie lipidogramu u chorych z ACS powinno być wykonane jak najwcześniej, gdyż w kolejnych dobach ulega on zmniejszeniu [24].

Statyny są podstawowymi lekami wykorzystywanymi w terapii hipercholesterolemii. Zmniejszają one syntezę cholesterolu w wątrobie, hamując kompetycyjnie aktywność reduktazy 3-hydroksy-3-metyloglutarylo-koenzymu A. Należą do najlepiej przebadanych leków stosowanych w prewencji zdarzeń sercowo-naczyniowych, a ich wpływ na redukcję śmiertelności z przyczyn sercowo-naczyniowych udowodniono w wielu badaniach klinicznych. Wśród statyn dostępnych w Polsce najsilniejsze działanie wywierają rosuwastatyna oraz atorwastatyna. Najmniejsza zalecana dawka rosuwastatyny 5-10 mg jest równoważna sile działania hipolipemizującego z 20-30 mg atorwastatyny i 30-40 mg simwastatyny. Oznacza to, że stosunek efektywności hipolipemizującej rosuwastatyny do atorwastatyny wynosi około 1:3 [25].

W przypadku nieosiągnięcia docelowych wartości stężenia LDL można dołączyć selektywny inhibitor wchłaniania cholesterolu - ezetimib, którego skuteczność potwierdzono w badaniu IMPROVE-IT [26]. Interesującą opcję terapeutyczną stanowi także nowa grupa leków, czyli inhibitory proproteinowej konwertazy subtylizyny/keksyny typu 9 (inhibitory PCSK9). Dwa z nich - ewolokumab oraz alirokumab - już dopuszczono do powszechnego użycia, jednak badania z ich zastosowaniem u pacjentów z ACS jeszcze trwają. Niemniej nowe wytyczne sytuują je jako lek trzeciego rzutu (po statynach i ezetimibie) u chorych po ACS służący do osiągnięcia docelowych wartości LDL-C.

Szczególną populację wśród chorych z ACS stanowią pacjenci z dyslipidemią aterogenną, u których stwierdza się podwyższone stężenie TG, obniżone stężenie HDL oraz wzrost stężenia małych, gęstych LDL. W leczeniu pacjentów z dyslipidemią aterogenną stosuje się fibraty, spośród których preferuje się fenofibrat, który jest obdarzony najmniejszym potencjałem interakcji w przypadku skojarzenia ze statyną. Fibraty zmniejszają stężenie TG, nie-HDL-C oraz małych gęstych LDL. Ponadto zwiększają stężenie HDL we krwi. U chorych z podwyższonym stężeniem LDL lekiem pierwszego wyboru jest statyna, a osiągnięcie docelowego stężenia LDL pozostaje podstawowym celem leczenia, chyba że stężenie TG przekracza $500 \mathrm{mg} / \mathrm{dl}$, wówczas fibrat stosuje się jako pierwszy preparat w profilaktyce zapalenia trzustki.

W jednej z analizy badania PROVE-IT TIMI 22 oceniono wpływ stężenia TG w trakcie leczenia statyną na ryzyko ponownego wystąpienia zdarzeń sercowo-naczyniowych po ACS w 30-dniowej obserwacji. Analizie poddano 4162 chorych hospitalizowanych z powodu ACS, których zrandomizowano do grupy leczonej atorwastatyną w dawce $80 \mathrm{mg}$ lub prawastatyną w dawce $40 \mathrm{mg}$. W badaniu wykazano, że niskie stężenie TG (< 150 mg/dl) związane było z mniejszym ryzykiem wystąpienia złożonego punktu końcowego zarówno w analizie jednoczynnikowej (HR 0,73, 95\% Cl 0,62-0,87; $p<0,001$ ), jak i wieloczynnikowej (HR 0,80, $95 \% \mathrm{Cl} 0,66-0,97 ; p=0,025)$. Każde obniżenie stężenia TG $010 \mathrm{mg} / \mathrm{dl}$ wiązało się ze zmniejszeniem ryzyka wystąpienia złożonego punktu końcowego o 1,6\%. Dane te sugerują, że stężenie TG u chorych po ACS mogłoby być rozpatrywane, obok stężenia LDL-C, jako cel terapeutyczny w leczeniu hipolipemizującym [27]. Podobne wyniki uzyskali Yun i wsp. [28].

Z kolei Schwartz i wsp. [29] analizie poddali związek między stężeniem TG i rokowaniem u pacjentów po ACS leczonych statynami. Oceniono zarówno długo-, jak i krótkoterminowy wpływ TG na ryzyko sercowo-naczyniowe po ACS, odpowiednio, w badaniach dal-OUTCOMES i MIRACLE (Multicenter InSync Randomized Clinical Evaluation). W analizie badania dal-OUTCOMES uwzględniono 15817 chorych po ACS losowo przydzielonych do grupy leczonej dalcetrapibem lub placebo (mediana obserwacji wynosiła 31 miesięcy). Z kolei w analizie badania MIRACL uwzględniono 1501 chorych po ACS leczonych atorwastatyną w dawce $80 \mathrm{mg}$ przez 16 tygodni. Stężenie TG na czczo było związane zarówno z długo-, jak i krótkoterminowym ryzykiem u chorych po ACS. W badaniu dal-OUTCOMES ryzyko względne między najwyższym i najniższym kwintylem (> $175 \mathrm{v} . \leq 80 \mathrm{mg} / \mathrm{dl}$ ) wynosiło 1,61 (95\% Cl 1,34-1,94). Z kolei w badaniu MIRACL ryzyko względne pomiędzy najwyższym i najniższym tercylem (> 195 v. $\leq 135 \mathrm{mg} / \mathrm{dl}$ ) wynosiło 1,5 (95\% Cl 1,05-2,15) [29]. Co ważne, Buturak i wsp. [30] wykazali, że stężenie TG koreluje ze stężeniem troponiny oznaczonej u pacjentów poddawanych zabiegom planowej angioplastyki wieńcowej (współczynnik korelacji $-r=0,435$, poziom istotności $-p<0,001)$. 
W badaniu Shah i wsp. [31] ocenie poddano dołączenie fenofibratu do statyny u pacjentów z ACS leczonych przezskórną angioplastyką wieńcową. Było to randomizowane, otwarte badanie w układzie grup równoległych. Włączono do niego 102 chorych z ACS przydzielonych do jednej z czterech grup: atorwastatyna (20 mg); simwastatyna (40 mg); atorwastatyna (10 mg) i fenofibrat (200 mg) oraz simwastatyna $(20 \mathrm{mg}$ ) i fenofibrat $(200 \mathrm{mg})$. W badaniu wykazano, że dołączenie fenofibratu do statyny wiązało się z istotnym zmniejszeniem stężenia TG i VLDL oraz ze wzrostem stężenia HDL. Ponadto wykazano także zmniejszenie stężenia fibrynogenu w osoczu.

Wyniki badań wskazują, że stężenie TG u chorych po ACS może być rozpatrywane, obok stężenia LDL-C, jako cel terapeutyczny w leczeniu hipolipemizującym, co jest szczególnie ważne u pacjentów z dyslipidemią aterogenną. Jednakże obecnie nie są dostępne badania oceniające twarde punkty końcowe u pacjentów z ACS, u których stosuje się leczenie skojarzone oparte na statynach i fibratach. Wydaje się zasadne zorganizowanie badania na odpowiednio dużej populacji chorych poddawanych zabiegom przezskórnej angioplastyki wieńcowej (zarówno ze stabilną chorobą wieńcową, jak i z ACS) i z długą obserwacją kliniczną, u których ta optymalna forma leczenia hipolipemizującego byłaby uwzględniona.

\section{Fibraty w nefrologii}

Rola leczenia hipolipemizującego przez obniżenie stężenia LDL-C w prewencji zdarzeń sercowo-naczyniowych u chorych na cukrzyce jest dobrze udokumentowana. Wyniki dużych badań klinicznych z zastosowaniem statyn udowodniły, że obniżenie lipoprotein LDL wiąże się z redukcją incydentów sercowo-naczyniowych o 30-40\% [32, 33]. Jednak leczenie dyslipidemii mieszanej wciąż budzi dyskusje wokół sposobu osiągnięcia normalizacji profilu lipidowego i wyników klinicznych leczenia. Analiza wyników badań z zastosowaniem statyn, a także dane z badań epidemiologicznych wskazują, że nawet u osób ze znacznym obniżeniem LDL-C, osiągającym wartości docelowe dla danego pacjenta, istnieje ryzyko związane z niskim stężeniem HDL-C i podwyższonym stężeniem TG [34].

Pierwszorzędowym celem leczenia pozostaje normalizacja stężenia cholesterolu zawartego w lipoproteinach niskiej gęstości LDL, głównej aterogennej frakcji surowicy. Ważne w leczeniu jest także stężenie nie-HDL-C, który jest uważany za alternatywny marker ryzyka. Jeżeli nie uzyska się zatem stężeń docelowych LDL oraz nie-HDL-C za pomocą statyn, można i należy rozważyć leczenie kombinacją statyny i fibratu. W metaanalizie badań 18 badań z zastosowaniem fibratów, obejmującej 45058 pacjentów, wykazano, że ich korzystny wpływ na redukcję zdarzeń sercowo-naczyniowych wynika z obniżenia stężenia TG. Stwierdzono, że leczenie fibratami wiązało się z istotną redukcją głównych incyden- tów naczyniowych (10\%), redukcją incydentów wieńcowych (13\%), a także redukcją ryzyka progresji mikroangiopatii (albuminurii o 14\%, retinopatii o 37\%). U chorych z cukrzyca typu 2 obserwowano również zmniejszenie ryzyka amputacji stopy po leczeniu fenofibratem [35].

W wynikach kolejnej metaanalizy wskazano, że stężenie nie-HDL-C pozwala lepiej oszacować ryzyko niż LDL-C, szczególnie u pacjentów chorych na cukrzycę, z hipertriglicerydemią oraz przewlekłą chorobą nerek [36]. Należy jednak pamiętać, że upośledzenie czynności nerek ogranicza, ze względu na istniejące przeciwwskazania, możliwości terapeutyczne zarówno w odniesieniu do wielu leków przeciwhiperglikemicznych, jak i innych leków stosowanych w terapii wielokierunkowej cukrzycy oraz schorzeń z nią współistniejących, w tym dyslipidemii. Podczas gdy dyslipidemia per se jest czynnikiem ryzyka progresji przewlekłej choroby nerek, dane dotyczące bezpieczeństwa stosowania fibratów w tej populacji, w tym obserwowany wzrost stężenia kreatyniny, pozostają niejednoznaczne. Na podstawie przeglądu systematycznego 10 badań obejmujących 16869 chorych z przewlekłą chorobą nerek łagodną do umiarkowanej należy stwierdzić, że fibraty obniżają stężenie cholesterolu całkowitego (o 0,32 mmol/l; $p=0,05), T G(00,56 \mathrm{mmol} / \mathrm{l} ; \mathrm{p}=0,03)$, ale nie LDL-C (o $0,01 \mathrm{mmol} / \mathrm{l} ; \mathrm{p}=0,83$ ) oraz powodują wzrost HDL-C (o $0,06 \mathrm{mmol} / \mathrm{l} ; \mathrm{p}=0,001$ ). U chorych na cukrzyce z eGFR w zakresie 30-59,9 ml/min/1,73 $\mathrm{m}^{2}$ fibraty zmniejszały ryzyko wystąpienia epizodów sercowo-naczyniowych (ryzyko względne [RR, relative risk] 0,70; 95\% Cl 0,54-0,89; $p=0,004)$ i zgonu z przyczyn sercowo-naczyniowych (RR 0,60; 95\% Cl 0,38-0,96; $p=0,03$ ), ale nie śmiertelności całkowitej i redukowały ryzyko progresji albuminurii (RR 0,86; 95\% Cl 0,76-0,98; $p=0,02$ ) przy jednoczesnym przejściowym wzroście stężenia kreatyniny w surowicy krwi (o 0,33 $\mu \mathrm{mol} / \mathrm{l} ; \mathrm{p}<0,001$ ) i redukcji eGFR (o 2,67 ml/min/ $/ 1,73 \mathrm{~m}^{2}, \mathrm{p}=0,01$ ). Odbywało się to jednak bez wpływu na ryzyko wystąpienia schyłkowej niewydolności nerek (RR 0,85; 95\% Cl 0,49-1,49; p = 0,575) [37].

Jak już wspomniano, redukcję liczby epizodów sercowo-naczyniowych u chorych na cukrzycę typu 2 obserwowano również w badaniu FIELD oraz badaniu ACCORD Lipid. Analiza wcześniej zdefiniowanych podgrup pacjentów w badaniu ACCORD Lipid sugeruje heterogenność efektu leczenia w zależności od płci - terapia skojarzona wywiera korzystny efekt redukujący incydenty sercowo-naczyniowe u mężczyzn, u kobiet zaś stwierdza się gorszy efekt. W badaniu wykazano również możliwość korzystnego efektu terapii skojarzonej w postaci redukcji o 30\% incydentów sercowo-naczyniowych u osób z równoczesnym wysokim stężeniem TG ( $\geq 204 \mathrm{mg} / \mathrm{dl}$ ) i niskim stężeniem HDL-C ( $\leq 34 \mathrm{mg} / \mathrm{dl}$ ). W żadnym z wymienionych badań przejściowy wzrost stężenia kreatyniny w surowicy krwi nie skutkował działaniami niepożądanymi w zakresie poważnych zdarzeń 
nerkowych, co sugeruje możliwe korzyści przy długotrwałej terapii [38-42].

Podsumowując, należy stwierdzić, że fibraty korzystnie wpływają na profil lipidowy i ryzyko wystąpienia epizodów sercowo-naczyniowych u chorych na cukrzycę typu 2 z łagodną do umiarkowanej przewlekłą chorobą nerek. Należy jednak mieć jednocześnie świadomość, że dostępne dane pochodzą jedynie $z$ analizy podgrup i brakuje obserwacji dotyczących chorych z bardziej zaawansowanymi stadiami przewlekłej choroby nerek, do stadium terminalnego włącznie. Stwarza to pilną potrzebę zaprojektowania i przeprowadzenia dużych prospektywnych badań randomizowanych oceniających rolę fibratów w redukcji ryzyka sercowo-naczyniowego u chorych z przewlekłą chorobą nerek, szczególnie ze współistniejącą cukrzycą.

\section{Fibraty w neurologii}

Udar mózgu jest drugą najczęstszą przyczyną zgonów na świecie i najczęstszą przyczyną nabytej niepełnosprawności u osób dorosłych w większości regionów świata. W Polsce zachorowalność na udar mózgu jest podobna jak w Europie i wynosi 177/100 000 u mężczyzn i 125/100 000 u kobiet [43], w Polsce jednak śmiertelność wczesna po udarze mózgu jest wyższa i wynosi około 30\% [44], 20-53\% chorych zaś pozostaje niesamodzielnych i wymaga pomocy [45]. Udar mózgu jest chorobą heterogenną, związaną nie tylko z miażdżycą dużych naczyń, ale również z chorobami małych naczyń, zakrzepicą żylną i chorobami serca. W większości badań dotyczących ryzyka udaru rozróżnia się przede wszystkim udary krwotoczne (HS, hemorrhagic stroke) i niedokrwienne (IS, ischemic stroke), natomiast udary niedokrwienne mogą mieć różną etiologię. Z tego wynikają rozbieżności dotyczące czynników ryzyka udarów niedokrwiennych i choroby niedokrwiennej serca oraz nieco odmienne podejście do profilaktyki pierwotnej i wtórnej obu chorób.

Zaburzenia lipidowe są dobrze udokumentowane jako czynnik ryzyka udaru niedokrwiennego mózgu, szczególnie o etiologii miażdżycowej [46]. Należy podkreślić, że wysokie stężenie cholesterolu całkowitego oraz LDL pozostaje udowodnionym czynnikiem ryzyka IS, podczas gdy stężenie cholesterolu poniżej 200 mg/dl koreluje z większym ryzykiem HS [47]. Na podstawie dostępnych badań nie udało się ustalić bezpiecznego stężenia cholesterolu, poniżej którego ryzyko udaru niedokrwiennego istotnie maleje. Badania HPS (Heart Protection Study) i SPARCL (Stroke Prevention by Aggressive Reduction in Cholesterol Levels) dotyczące leczenia statynami chorych po udarze mózgu pokazały, że statyny (odpowiednio, simwastatyna $40 \mathrm{mg} / \mathrm{d}$. i atorwastatyna $80 \mathrm{mg} / \mathrm{d}$.) istotnie redukują ryzyko nawrotu udaru u chorych po przebytym IS lub przemijającym niedokrwieniu mózgu (TIA, transient ischemic attack) [48, 49]. W metaanalizie badań u chorych z udarem stwierdzono również, że redukcja LDL-C o 10\% zmniejsza rocznie ryzyko udaru o 15,6\% [50].

Na podstawie obecnych badań nie można jednoznacznie ocenić wpływu hipertriglicerydemii i niskiego stężenia HDL-C na ryzyko udaru niedokrwiennego [51, 52]. Opublikowana w 2015 roku analiza oparta na badaniu Framingham pokazała, że w ciągu 9-letniej prospektywnej obserwacji pacjentów nieobciążonych IS Iub TIA HDL-C nie większe niż $40 \mathrm{mg} / \mathrm{dl}$ było związane z podwyższonym ryzykiem udaru niedokrwiennego ([95\% Cl] 1,59 [1,23-2,05]; $p<0,001$ ), natomiast stężenie TG nie wpływało na ryzyko IS [53]. Badanie to potwierdziło wcześniejsze analizy, według których na każdy wzrost stężenia HDL-C o 1 mmol/I ryzyko IS zmniejsza się rocznie o 11-15\% [10]. W 2008 roku opublikowano badanie Copenhagen City Heart Study, w którym wzięło udział 13956 uczestników między 20. a 93. rokiem życia (prospektywna obserwacja w latach 1976-2007). Wykazano w nim, że stężenie TG niemierzone na czczo koreluje z ryzykiem udaru u mężczyzn. Mężczyźni z podwyższonymi stężeniami TG niemierzonymi na czczo mieli współczynnik ryzyka udaru niedokrwiennego w zakresie: od 1,4 (95\% Cl $0,9-2,1)$ dla stężenia TG $89-176 \mathrm{mg} / \mathrm{dl}$ do $3,2(95 \% \mathrm{Cl}$ 1,7-6,2) dla stężenia powyżej $443 \mathrm{mg} / \mathrm{dl}(\mathrm{p}<0,001 \mathrm{dla}$ trendu). W nielicznych badaniach, w których analizowano różną etiologię IS, hipertriglicerydemia i niskie stężenie HDL zawsze były związane ze zwiększonym ryzykiem IS o etiologii miażdżycowej. Badania te obejmują jednak zwykle nieduże grupy chorych [54].

Fibraty mogą powodować potencjalne korzyści dla leczenia i prewencji udaru mózgu o etiologii miażdżycowej. Po pierwsze, mogą redukować lub hamować rozwój zmian miażdżycowych w dużych tętnicach [54]. W niektórych populacjach pacjentów, na przykład u osób z nadciśnieniem tętniczym, chorych na cukrzycę lub po zawale serca, leczonych statynami, fibraty mogą stanowić o dodatkowym zmniejszeniu ryzyka udaru mózgu ponad to osiągnięte przez statyny [55]. W populacji osób starszych powyżej 65. roku życia wykazano, że fibraty i statyny w równym stopniu redukują ryzyko udaru mózgu o 30\% w ciągu 9 lat obserwacji w prewencji pierwotnej u osób nieobciążonych chorobami naczyniowymi [56]. W badaniach eksperymentalnych stwierdzono, że fibraty, przede wszystkim fenofibrat, wykazują potencjalne działanie neuroprotekcyjne zmniejszające objętość ogniska zawałowego lub hamujące wtórne ukrwotocznienie po trombolizie. Chociaż badania eksperymentalne są obiecujące, na razie nie podjęto odpowiednich badań klinicznych [57].

W badaniach klinicznych, takich jak ACCORD Lipid, nie stwierdzono przydatności fibratów jako leków prewencyjnych w profilaktyce wtórnej udaru mózgu. W metaanalizie obejmującej 10 randomizowanych badań, w których uczestniczyło 37791 pacjentów, wskazano że fibraty (klofibrat, bezafibrat, gemfibrozil, fenofibrat) nie wpływają na ryzyko 
udaru w prewencji pierwotnej lub wtórnej [58]. Metaanaliza z bazy Cochrane, opublikowana w 2015 roku, obejmująca 13 badań, w których wzięło udział 16112 uczestników, wykazała, że fibraty nie wpływają na redukcję ryzyka IS [59]. Odwrotną tendencję odnotowano dla udaru krwotocznego - wysokie stężenia cholesterolu całkowitego i nie-HDL-C były związane ze zmniejszonym ryzykiem udaru, ale trudno to wytłumaczyć i pojawia się wiele wątpliwości metodologicznych związanych z tą obserwacją. Tak samo wysokie stężenie HDL-C było związane ze zwiększonym ryzykiem udaru krwotocznego. Kontrowersje te wymagają wyjaśnienia przed podjęciem dużych badań klinicznych dotyczących zastosowania fibratów w prewencji wtórnej udarów.

Neuropatia w cukrzycy typu 2 dotyczy około połowy pacjentów i jest jednym z głównych powikłań cukrzycy wynikających z zaburzeń w mikrokrążeniu. Głównym czynnikiem ryzyka neuropatii jest hiperglikemia, która poza uszkodzeniem naczyń wiąże się z zaburzeniami metabolizmu lipidów w komórkach nerwowych oraz zmniejszonym wytwarzaniem czynników troficznych. Oprócz regulacji glikemii dodatkowym niezależnym czynnikiem zmniejszającym ryzyko neuropatii wydaje się zmniejszenie stężenia niektórych frakcji lipidów. W badaniu obserwacyjnym Fremantle Diabetes Study, przeprowadzonym wśród pacjentów chorych na cukrzycę typu 2, leczenie hipolipemizujące, a przede wszystkim przyjmowanie fenofibratu, wiązało się z mniejszym ryzykiem neuropatii w ciągu 5 lat obserwacji [60].

Uważa się, że zmniejszenie stężenia wybranych frakcji lipidów w neuropatii cukrzycowej ma z jednej strony wpływ na szybkość powstawania mikroangiopatii, z drugiej zaś leki hipolipemizujące mogą mieć dodatkowe działanie promujące lepsze ukrwienie tkanek, w tym nerwów obwodowych. Jedną z dróg, za pomocą której aktywuje się angiogeneza w niedokrwionych tkankach, jest aktywacja receptora aktywowanego przez proliferatory peroksysomów $\alpha$ (PPAR- $\alpha$, peroxisome proliferator-activated receptor $\alpha$ ). Aktywacja PPAR- $\alpha$ zmniejsza lub hamuje działanie kilkunastu mediatorów uszkodzenia naczyń, w tym mediatorów stanu zapalnego, a także powstawanie reaktywnych nadtlenków. Fenofibrat jest aktywatorem PPAR- $\alpha$, przez który reguluje stężenie TG i HDL-C, a jednocześnie wpływa na metabolizm komórek nerwowych i stymuluje produkcję tlenku azotu (NO, nitric oxide) przez indukowanie endotelialnej syntazy. W modelu eksperymentalnym cukrzycy typu 2 u myszy spontanicznie rozwijających cukrzyce (myszy C57BL/KsJ-db/ /db z mutacją genu dla receptora leptyny) wykazano, że fenofibrat chroni przed rozwojem neuropatii [61]. Dodatkowo fenofibrat obniża stężenie toksycznych sfingolipidów (1-deoksy-sfingolipidy) zaangażowanych w patomechanizm neuropatii cukrzycowej, których stężenie wzrasta w zespole metabolicznym i cukrzycy typu 2 [20]. Na podstawie istniejących obecnie danych z badań klinicznych nie można jednoznacznie zalecić stosowania fibratów w celu prewencji lub leczenia neuropatii u chorych na cukrzycę, należy jednak zwrócić na tę zależność uwagę.

\section{Fibraty w diabetologii}

Dyslipidemia aterogenna stanowi bardzo typowy problem w diabetologii. W badaniu UKPDS (United Kingdom Prospective Diabetes Study) u 5102 chorych z nowo wykrytą cukrzycą typu 2 stwierdzono znamiennie niższe stężenie w surowicy HDL-C i wyższe TG w porównaniu z osobami bez cukrzycy. Oszacowano również, że u pacjentów z nowo wykrytą cukrzycą typu 2 wzrost stężenia w surowicy LDL-C o 38,61 mg/dl zwiększał ryzyko choroby wieńcowej o 57\%. Natomiast wzrost stężenia HDL-C o 3,86 mg/dl redukował to ryzyko o 15\% [62]. Kluczową rolę w patogenezie charakterystycznych zmian w profilu lipidowym odgrywa insulinooporność zarówno wątroby, jak i tkanki tłuszczowej. Często aterogenna dyslipidemia w cukrzycy manifestuje się jako niealkoholowa stłuszczeniowa choroba wątroby (NAFLD, nonalcoholic fatty liver disease).

Z zaburzeniami gospodarki lipidowej pod postacią hipertriglicerydemii mamy często do czynienia w cukrzycy typu 1. Wiąże się ona z okresami niewyrównania gospodarki węglowodanowej i wynika między innymi z okresowego bezwzględnego niedoboru insuliny. Poprawa wyrównania gospodarki węglowodanowej przez skuteczną insulinoterapię zwykle doprowadza do normalizacji stężenia TG.

Ocenie skuteczności leczenia aterogennej dyslipidemii fibratami w cukrzycy typu 2 dedykowane były dwie duże, wspomniane już próby kliniczne FIELD i ACCORD Lipid. Wyniki tych badań wskazują, że w wyniku zastosowania fibratów zmniejsza się ryzyko wystąpienia zdarzeń sercowo-naczyniowych, ale nie wiąże się to ze spadkiem śmiertelności całkowitej. W badaniu FIELD, w którym uczestniczyło 9795 chorych na cukrzyce typu 2 (w tym 75\% w prewencji pierwotnej), stwierdzono nieznamienny spadek o 11\% incydentów sercowo-naczyniowych w grupie przyjmującej fenofibrat w dawce 200 mg w porównaniu z grupą otrzymującą placebo [63]. Na uwagę zasługuje jednak działanie fibratu zapobiegające powikłaniom mikronaczyniowym (zahamowanie progresji albuminurii o 15\% oraz potrzeby laseroterapii z powodu retinopatii o 30\%). Ponieważ hipertriglicerydemia jest uznanym czynnikiem ryzyka rozwoju neuropatii cukrzycowej, obniżenie stężenia TG w badaniu FIELD przyniosło redukcję o 46\% małych amputacji kończyn dolnych z powodu zespołu stopy cukrzycowej neuropatycznej. Analiza post hoc tego badania wykazała zmniejszenie o 27\% ryzyka wystąpienia zdarzeń sercowo-naczyniowych (śmierć z przyczyn sercowo-naczyniowych, zawał serca, udar mózgu, potrzeba rewaskularyzacji) u pacjentów z aterogenną dyslipidemią (stężenie TG > 200 mg i HDL-C < 40 mg/dl), co wyrażało się małą liczbą NNT (number needed to treat; 23 osoby przez 5 lat) w porównaniu z całą grupą osób leczonych (NNT - 70 osób). 
W trwającej 4,5 roku próbie klinicznej ACCORD Lipid, obejmującej 5518 pacjentów chorych na cukrzycę, oceniano wpływ simwastatyny w dawce $20 \mathrm{mg} /$ dobę w skojarzeniu z fenofibratem w dawce $160 \mathrm{mg} /$ dobę lub z placebo na ryzyko zdarzeń sercowo-naczyniowych [64]. Stwierdzono redukcję o 11\% ryzyka względnego występowania zdarzeń sercowo-naczyniowych (śmierć z przyczyn sercowo-naczyniowych, zawał serca, udar mózgu, potrzeba rewaskularyzacji) w grupie pacjentów otrzymujących fenofibrat, różnica ta jednak nie okazała się istotna statystycznie. Jednak w subanalizie badania w podgrupie chorych na cukrzyce (485 osób) z aterogenną dyslipidemią ( $T G \geq 204 \mathrm{mg} / \mathrm{dl}$, HDL-C $<34 \mathrm{mg} / \mathrm{dl}$ ) stwierdzono, że terapia kompleksowa statyna + fibrat była skuteczna, co wyrażało się $w$ redukcji ryzyka incydentów sercowo-naczyniowych o 31\% ( $p=0,057)$ w porównaniu z grupą pacjentów leczonych samą statyną, a liczba NNT wynosiła w tej podgrupie 20 osób przez 5 lat. W leczeniu aterogennej dyslipidemii w cukrzycy najważniejsze znaczenie ma poprawa wyrównania gospodarki węglowodanowej, a wśród leków hipolipemizujących wiodącą rolę odgrywa fenofibrat nie tylko ze względu na swój zasadniczy mechanizm działania, ale również być może z powodu oddziaływania plejotropowego.

Według Stanowiska Polskiego Towarzystwa Diabetologicznego „Zalecenia kliniczne dotyczące postępowania u chorych na cukrzycę 2016" w leczeniu zaburzeń lipidowych w cukrzycy stosuje się statynę, a po osiągnięciu docelowych stężeń LDL-C i dalszego utrzymywania się podwyższonego stężenia TG (>200 mg/dl) zaleca się rozważenie terapii kompleksowej z fenofibratem [65].

\section{Fibraty w okulistyce}

Mikroangiopatia to czynnościowe i morfologiczne zmiany w układzie naczyń włosowatych oraz w żyłach i tętnicach o średnicy poniżej $100 \mu \mathrm{m}$. W skład mikrokrążenia wchodzą: tętniczki przedwłosowate, sieć naczyń włosowatych oraz żyłki pozawłosowate. Naczynia te różnią się od naczyń o większym kalibrze brakiem typowej dla większych naczyń budowy warstwowej. Ściana w mikrokrążeniu składa się bowiem ze śródbłonka błony podstawnej, pojedynczych komórek mięśni gładkich (poza siecią naczyń włosowatych) oraz perycytów. Perycyty pełnią funkcję odżywcze i ochronne. Są bardzo wrażliwe na wszelkie zmiany hemodynamiczne, co doprowadza do ich apoptozy [66, 67]. Mikroangiopatia cukrzycowa jest wynikiem przewlekłej hiperglikemii oraz nakładających się czynników, takich jak nadciśnienie tętnicze, podwyższone stężenie lipidów we krwi i zaburzenia przepływu krwi. W przebiegu mikroangiopatii cukrzycowej najważniejsze klinicznie zmiany zachodzą w obrębie naczyń siatkówki (retinopatia), nerek (nefropatia), układu nerwowego (neuropatia), serca (kardiomiopatia). Najważniejszym czynnikiem ryzyka rozwoju i progresji retinopatii cukrzycowej jest długość trwania choroby. Częstość retinopatii cukrzycowej w cukrzycy typu 2 wzrasta wraz z czasem trwania choroby [68]. Szacuje się, że w cukrzycy typu 2 już w momencie rozpoznania u 5\% pacjentów występują zmiany o cechach retinopatii cukrzycowej. Odsetek ten wzrasta do $25 \%$ po 15 latach trwania cukrzycy, osiągając niemal 60\% po 25 latach od początku trwania choroby. Najcięższa, proliferacyjna postać retinopatii cukrzycowej występuje u ponad $15 \%$ po 30 latach trwania cukrzycy. Rosnąca częstość występowania cukrzycy sprawia, że powikłania oczne cukrzycy są główną przyczyną ślepoty w populacji osób w wieku produkcyjnym (20.-65. rż.) w krajach rozwiniętych [69]. Wykazano, że u chorych na cukrzyce występuje 25-30-krotnie wyższe ryzyko ciężkiej utraty widzenia niż u osób zdrowych. Powikłania oczne cukrzycy mogą dotyczyć każdej struktury oka, natomiast to właśnie retinopatia cukrzycowa jest główną przyczyną pogorszenia wzroku i utraty widzenia. Do najczęstszych bezpośrednich przyczyn utraty wzroku należą: krwotok przedsiatkówkowy, wylew krwi do ciała szklistego, cukrzycowy obrzęk plamki, trakcyjne odwarstwienie siatkówki, jaskra neowaskularna. Pozostałymi zidentyfikowanymi czynnikami ryzyka rozwoju retinopatii cukrzycowej są: zła kontrola glikemii (z podwyższonymi stężeniami hemoglobiny glikowanej $\left.\left[\mathrm{HbA}_{10}\right]\right)$, otyłość, nadciśnienie tętnicze, zaburzenia gospodarki lipidowej (podwyższone stężenie LDL-C, podwyższone stężenie TG, obniżone stężenie HDL-C), ciąża, obecność nefropatii cukrzycowej, palenie tytoniu.

U podłoża mikroangiopatii cukrzycowej leży hiperglikemia. W efekcie długotrwałej hiperglikemii dochodzi do aktywacji wzajemnie oddziałujących następujących procesów biologicznych: zwiększenie stresu oksydacyjnego, przewlekłe zapalenie, aktywacja kinazy białkowej C, szlak poliolowy, nieenzymatyczna glikacja białek oraz aktywacja receptorów PPAR- $\alpha$. W wyniku stresu oksydacyjnego dochodzi do powstania zwiększonej liczby wolnych rodników tlenowych wykazujących działanie naczyniokurczące przez tworzenie $\mathrm{H}_{2}, \mathrm{O}_{2}, \mathrm{OH}^{*}$, które stymulują produkcję prostanoidów o własnościach wazokonstrykcyjnych. Dodatkowo zmniejsza się biodostępność NO z powodu łączenia się $\mathrm{z}$ anionami ponadtlenkowymi $\mathrm{O}_{2}^{-}$produkowanymi w nadmiarze. Tlenek azotu ma działanie rozkurczające naczynia, antyproliferacyjne i przeciwzapalne. W wyniku tych procesów dochodzi do zaburzenia równowagi między czynnikami naczyniorozkurczowymi a naczynioskurczowymi, co doprowadza do zwiększenia napięcia ściany naczyń i zmniejszenia przepływu krwi. Skutkuje to niedotlenieniem obszarów siatkówki.

W wyniku przewlekłego podwyższenia stężenia glukozy we krwi granulocyty (PMN, polymorphonuclear leukocytes) tracą zdolność do odkształcania, między innymi w następstwie glikacji białek błony komórkowej. Dodatkowo ulegają nasilonej aktywacji z towarzyszącą produkcją interleukiny 8 
(IL-8) oraz pojawieniem się na PMN molekuł powierzchniowych CD11/CD18 i selektyn L. Ponadto dochodzi do zwiększenia ekspresji na komórkach śródbłonka naczyń cząsteczek adhezyjnych ICAM 1 i 2 oraz śródbłonkowych selektyn E i P. Doprowadza to do zwiększenia adhezji i agregacji komórek stanu zapalnego, leukoembolizacji (czopowanie naczyń mikrokrążenia przez PMN). Zwiększone stężenie IL-8 pobudza uwalnianie enzymów proteolitycznych z ziarnistości PMN i nasiloną apoptozę komórek śródbłonka. Aktywacja kinazy białkowej C (PKC, protein kinase $\mathrm{C}$ ) doprowadza do wydzielania czynników: zwiększenie inhibitora aktywatora plazminogenu 1, zwiększenie stężenia fibronektyny, zwiększenie stężenia ET-1, zwiększenie ekspresji jądrowego czynnika transkrypcyjnego

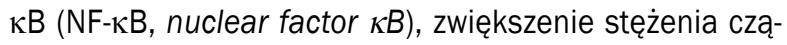
steczek adhezji komórkowej naczyń 1 (VCAM-1, vascular cell adhesion molecule 1), cząsteczek adhezji międzykomórkowej 1 (ICAM-1, intercellular adhesion molecule-1), zwiększenie stężenia transformującego czynnika wzrostu $\beta$ (TGF- $\beta$, transforming growth factor $\beta$ ) oraz zwiększenie stężenia kinaz aktywowanych mitogenami (MAP-kinazy, mitogen-activated protein kinases). Czynniki te wpływają na: wzrost proliferacji komórek i syntezy białek macierzy pozakomórkowej, pogrubienie błon podstawnych naczyń, zwężenie naczyń, nasilenie procesów krzepnięcia, nasilenie transkrypcji genów zaangażowanych w rozwój reakcji zapalnej i przewlekłe zmiany w naczyniach oraz na wzrost adhezji leukocytów. Z powodu nadmiaru glukozy we krwi dochodzi do aktywacji alternatywnego szlaku metabolizmu glukozy i przekształcania jej w sorbitol. Enzymem katalizującym jest reduktaza aldolazy, której ekspresja wzrasta w warunkach hiperglikemii. Dochodzi do wzrostu stężenia sorbitolu w komórce, co zwiększa wewnątrzkomórkowe ciśnienie osmotyczne, doprowadza do obrzęku komórki i jej apoptozy. W procesie produkcji sorbitolu dochodzi do spadku stężenia zredukowanego dinukleotydu nikotynoamidoadeninowego NADPH (konieczny również do aktywacji reduktazy glutationu). Niedobór NADPH doprowadza do stanu tzw. hipoksji metabolicznej i dalszego nasilenia stresu oksydacyjnego.

Nienzymatyczna glikacja białek doprowadza do powstania końcowych produktów glikacji białek (AGE, advanced glycation end products). Skutkuje to zmianą budowy oraz funkcji białek strukturalnych, receptorowych, transportowych i enzymatycznych. Spolimeryzowane i usieciowane białka tracą własności biologiczne, są oporne na degradację proteolityczną, co utrudnia ich usuwanie z komórek i tkanek. Kumulacja takich produktów w postaci złogów powoduje usztywnienie ścian naczyń w wyniku pogrubienia ściany podstawnej kapilar. Dodatkowo końcowe produkty glikacji białek za pomocą swoistych receptorów (tzw. RAGE, receptors for AGE) aktywują monocyty, makrofagi oraz komórki mezangium.
Prowadzi to do ekspresji czynnika transkrypcyjnego NF-кB, co wywołuje zwiększoną produkcję czynników prozapalnych (IL-1, IL-6, czynnik martwicy nowotworu [TNF- $\alpha$, tumor necrosis factor $\alpha$ ]) oraz białek adhezyjnych (VCAM-1, ICAM-1). Doprowadza to do nasilonej chemotaksji i proliferacji komórek mięśni gładkich oraz makrofagów. Receptor PPAR- $\alpha$ należy do dużej nadrodziny receptorów jądrowych. Jego aktywacja odgrywa decydującą rolę w regulacji oksydacji kwasów tłuszczowych, metabolizmie lipidów oraz procesach zapalnych i może regulować różne metaboliczne i wewnątrzkomórkowe ścieżki sygnałowe, które prowadzą do powikłań mikroangiopatycznych. Wszystkie opisane procesy przyczyniają się do uszkodzenia naczyń krwionośnych siatkówki, przejawiającego się zanikiem perycytów, pogrubieniem błony podstawnej, upośledzeniem szczelności śródbłonka, zwiększeniem agregacji erytrocytów i trombocytów, upośledzeniem procesów fibrynolizy oraz zmniejszeniem elastyczności erytrocytów i leukocytów. W obrazie dna oka doprowadza to do powstania zmian charakterystycznych dla retinopatii cukrzycowej: mikrotętniaków, obrzęku, wybroczyn, wysięków twardych. W późniejszych fazach może dochodzić do zamknięcia światła naczyń, co skutkuje niedokrwieniem i niedotlenieniem obszarów siatkówki. Może to skutkować mikrozawałami w siatkówce z obecnością tak zwanych kłębków waty. Długo utrzymujące się niedotlenienie nasila produkcję czynników wazoproliferacyjnych, głównie naczyniowo-śródbłonkowego czynnika wzrostu (VEGF, vascular endothelial growth factor), i nowotwórstwa naczyniowego. Nowo powstające naczynia są niepełnowartościowe, podatne na pęknięcia oraz nadmiernie przepuszczalne. Doprowadza to do wylewów krwi, co bezpośrednio zagraża widzeniu.

Udowodnionymi sposobami zmniejszenia ryzyka rozwoju retinopatii cukrzycowej są dobra kontrola glikemii z utrzymywaniem niskiego stężenia $\mathrm{HbA}_{1 \mathrm{c}}$ oraz normalizacja wartości ciśnienia tętniczego [70-72]. W ostatnich latach zwrócono uwagę na aterogenną dyslipidemię jako istotny czynnik rozwoju retinopatii cukrzycowej. Tego typu dyslipdemia typowo występuje u osób z zespołem metabolicznym i chorych na cukrzyce typu 2 [73]. W licznych badaniach, takich jak REALIST (The Verona Diabetes Study, REsiduAl risk, LIpids and Standard Therapies), ADVANCE (Action in Diabetes and Vascular disease: PreterAx and Diamicron MR Controlled Evaluation) oraz STENO-2, udowodniono rolę aterogennej dyslipiedemii w rozwoju powikłań mikroangiopatycznych. W świetle tych badań leczenie zaburzeń lipidowych u pacjenta chorego na cukrzycę powinno zmniejszyć częstość rozwoju retinopatii cukrzycowej. Badaniem oceniającym skutek leczenia zaburzeń lipidowych w cukrzycy jest opublikowane w 2010 roku, wspomniane już badanie ACCORD EYE [74]. Badanie ACCORD EYE stanowiło podgrupę większego badania ACCORD oceniającego różne 
formy terapii w celu zapobiegania wystąpieniu incydentu sercowo-naczyniowego. Do ramienia badania ACCORD EYE włączono 2856 pacjentów chorych na cukrzyce typu 2. Celem badania było stwierdzenie, czy którakolwiek z trzech badanych form leczenia (intensywna kontrola glikemii, intensywna kontrola RR, leczenie kompleksowe zaburzeń lipidowych statyną i fenofibratem) zmniejsza ryzyko rozwoju lub progresji retinopatii cukrzycowej w porównaniu ze standardową terapią. W ciągu 4 lat wykonywano 7-polową fotografię dna oka, którą stopniowano według skali ciężkości ETDRS (Early Treatment Diabetic Retinopathy Study). W badaniu oceniano ciężkość retinopatii cukrzycowej w 17-punktowej skali progresji ETDRS, konieczność wykonania fotokoagulacji laserowych i konieczność wykonania witrektomii.

W grupie intensywnej kontroli glikemii po 4 latach progresję retinopatii cukrzycowej obserwowano u 7,3\% badanych (104 z 1429) w porównaniu z 10,4\% (149 z 1427) w grupie standardowej $(p=0,003)$. W grupie intensywnie kontrolującej glikemię ze względu na częstsze występowanie hipoglikemii oraz incydentów sercowo-naczyniowych co prowadziło do podwyższonej śmiertelności - wycofano się z tego ramienia badania po 3,5 roku. Równie istotna była kontrola ciśnienia tętniczego. Do tego ramienia badania włączono 1263 pacjentów. Wyjściowe ciśnienie tętnicze skurczowe (SBP, systolic blood pressure) wynosiło średnio $137 \mathrm{~mm} \mathrm{Hg}$. Po roku badania średnio SBP wynosiło 117 mm Hg w grupie intensywnej kontroli ciśnienia oraz 133 mm Hg w grupie standardowej kontroli. Po 4 latach nie stwierdzono różnic istotnych statystycznie między grupami w zakresie progresji retinopatii cukrzycowej, którą stwierdzono u 10,4\% (67 z 647) w grupie intensywnej kontroli ciśnienia oraz 8,8\% (54 z 616) w grupie standardowej. Autorzy postulują, że prawdopodobnie średni SBP 133 mm Hg, jakie osiągnięto w grupie standardowej, działa wystarczająco ochronnie.

Kolejnym ważnym czynnikiem ochronnym okazał się wpływ na profil lipidowy. Do tego ramienia badania włączono 1593 pacjentów z zaburzeniami lipidowymi. Celem tej części badania było porównanie wyników leczenia simwastatyną w monoterapii lub simwastatyną skojarzoną z fenofibratem i ich wpływ na progresję retinopatii cukrzycowej. Wyjściowo średnie stężenie lipidów wynosiło: HDL-C $38 \mathrm{mg} / \mathrm{dl}$, LDL-C 93 mg/dl oraz TG 162 mg/dl. W badaniu wykazano brak różnic statystycznych między grupami w zakresie stężenia LDL-C ( $p=0,68)$, natomiast $w$ grupie leczonej terapią kompleksową stwierdzono istotnie statystyczny wzrost stężenia HDL-C w porównaniu z grupą leczoną monoterapią ( $p=0,002$ ). W grupie terapii kompleksowej stwierdzono również istotnie statystycznie niższe stężenie TG w porównaniu z grupą leczoną tylko simwastatyną $(p<0,001)$. Ponadto $w$ grupie leczonej fenofibratem i statyną zaobserwowano istotnie statystycznie mniejszą progresję retinopatii cukrzycowej $(6,5 \%$ [52 z 806] w porównaniu z 10,2\% [80 z 787]; $p=0,006$ ). W grupie otrzymującej leczenie skojarzone nie zaobserwowano częstszych powikłań, takich jak rabdomioliza czy wzrost transaminaz. Badanie ACCORD EYE potwierdziło korzystny wpływ terapii kompleksowej statyna-fenofibrat na zmniejszenie ryzyka rozwoju i progresji retinopatii cukrzycowej. Należy podkreślić, że wpływ fenofibratu był niezależny od wartości glikemii. Korzystne działanie fenofibratu na rozwój i progresję retinopatii cukrzycowej wynika nie tylko z działania leku na profil lipidowy, ale również z aktywności przeciwzapalnej, antyangiogennej, antyapoptotycznej oraz antyoksydacyjnej (ryc. 1) [75].

Podsumowując, zapobieganie ciężkim powikłaniom okulistycznym cukrzycy wymaga interdyscyplinarnego podejścia i współpracy specjalistów z różnych dziedzin (diabetolog, kardiolog, nefrolog, okulista). Należy poinformować chorego o ryzyku powikłań okulistycznych w przebiegu cukrzycy. Warto zachęcać chorych na cukrzyce bez retinopatii cukrzycowej, aby raz do roku poddawali się badaniu okulistycznemu z rozszerzeniem źrenic. Należy poinformować pacjentów, że skuteczne leczenie retinopatii cukrzycowej zależy od wdrożenia leczenia w odpowiednim czasie, niezależnie od dobrej ostrości wzroku oraz braku objawów. Bardzo istotne jest obniżenie stężenia lipidów w osoczu krwi, a u wybranych chorych - zastosowanie profilaktyki leczeniem skojarzonym.

\section{Terapia dyslipidemii aterogennej w świetle obowiązujących wytycznych}

Kompleksowe podejście do leczenia zaburzeń lipidowych jest zalecane przez obowiązujące wytyczne. Terapia dyslipidemii aterogennej opiera się na dodaniu fibratu do statyny w przypadku utrzymującego się podwyższonego stężenia TG i niskiego stężenia HDL-C (cech dyslipidemii aterogennej) mimo leczenia statyną albo w przypadku nie osiągnięcia docelowego stężenia nie-HDL-C.

Obowiązujące Wytyczne Polskiego Towarzystwa Diabetologicznego wskazują, że w podgrupie chorych na cukrzycę typu 2, cechujących się stężeniem TG powyżej $200 \mathrm{mg} / \mathrm{dl}(>2,3 \mathrm{~mm} / \mathrm{l})$ i stężeniem HDL-C mniejszym niż $34 \mathrm{mg} / \mathrm{dl}(<0,88 \mathrm{mmol} / \mathrm{l})$, leczonych statyną, dołączenie fenofibratu wiąże się z dodatkową redukcją incydentów sercowo-naczyniowych [76]. Wytyczne ESC dotyczące terapii dyslipidemii zalecają połączenie statyny z fibratem, w szczególności fenofibratem, bezafibratem lub ciprofibratem, u pacjentów z towarzyszącą hipertriglice- 


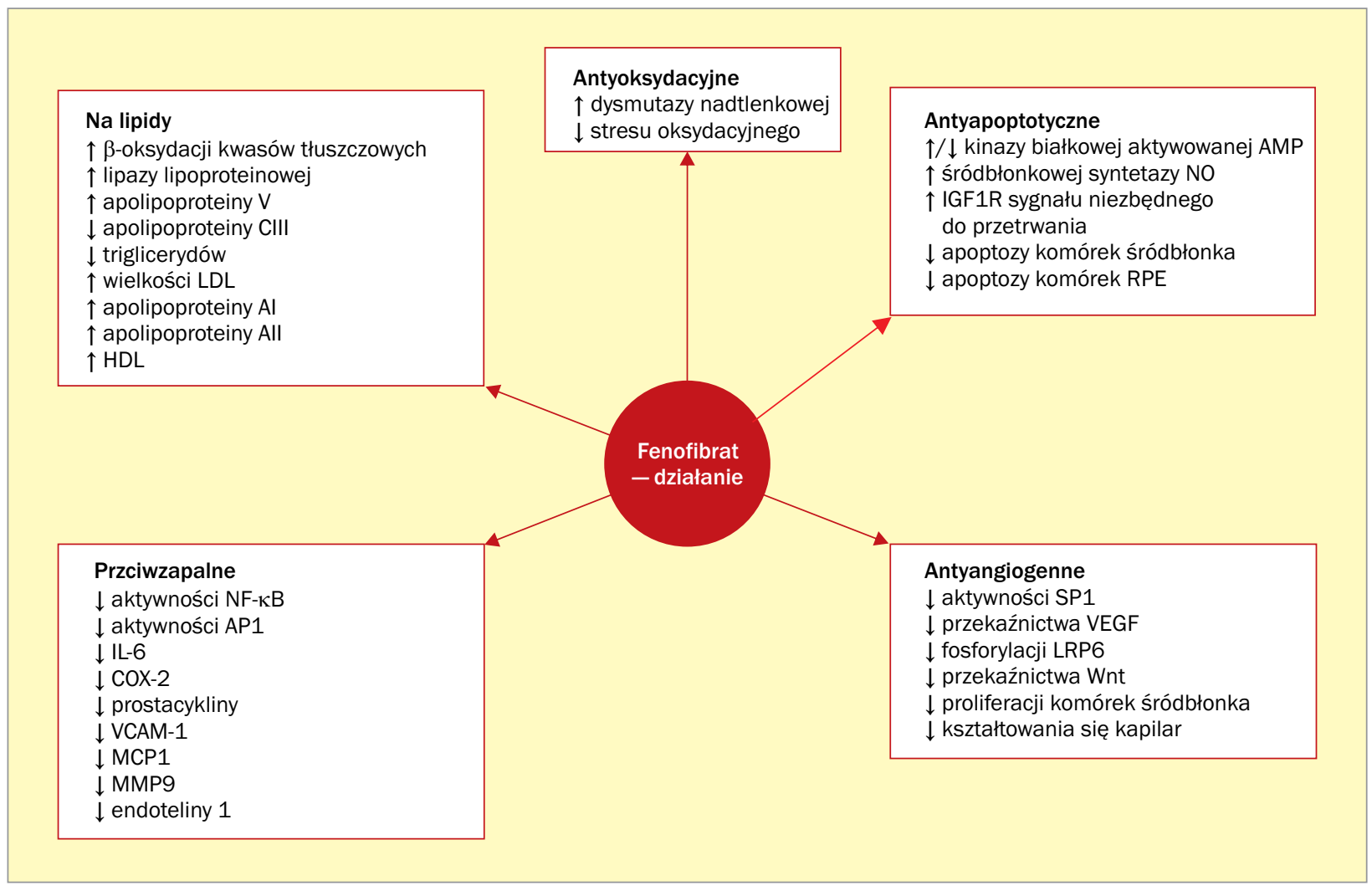

Rycina 1. Profil działania fenofibratu; AMP (adenosine monophosphate) - monofosforan adenozyny; COX-2 (cyclooxygenase-2) - cyklooksygenaza 2; HDL (high-density lipoprotein) - lipoproteiny o wysokiej gęstości; NF-kB (nuclear factor kB) - jądrowego czynnika transkrypcyjnego kB; IL - interleukina; LDL (low-density lipoprotein) - lipoproteiny o niskiej gęstości; MCP-1 (monocyte chemotactic protein-1) - białko chemotaktyczne monocytów 1; MMP9 (matrix metalloproteinase 9) - metaloproteinazy macierzy 9; N0 - tlenek azotu; VCAM-1 (vascular cell adhesion molecule 1) - cząsteczka adhezji komórkowej naczyń 1; VEGF (vascular endothelial growth factor) - naczyniowo-śródbłonkowy czynnik wzrostu

rydemią i/lub niskim stężeniem HDL-C [1]. Wytyczne ESC dotyczące cukrzycy, stanu przedcukrzycowego i chorób układu sercowo-naczyniowego, opracowane we współpracy z Europejskim Towarzystwem Badań nad Cukrzycą (EASD, European Association for the Study of Diabetes), potwierdzają, że stosowanie fibratów wiąże się z korzyściami klinicznymi w postaci zmniejszenia poważnych zdarzeń sercowo-naczyniowych [77]. Najnowsze wytyczne dotyczące prewencji chorób sercowo-naczyniowych wskazują fibraty, zwłaszcza fenofibrat, jako korzystny lek w terapii hipertriglicerydemii, aterogennej dyslipidemii u chorych na cukrzyce, oraz w terapii kompleksowej ze statyną [2]. W dokumencie Sekcji Farmakoterapii Sercowo-Naczy- niowej - II Deklaracji Sopockiej - będącym swoistym praktycznym kompendium postępowania w dyslipidemii podkreśla się, że leczeniu chorych z dyslipidemią aterogenną lub hipertriglicerydemią należy stosować fibraty, spośród których preferowany jest fenofibrat, obdarzony najmniejszym potencjałem interakcji w przypadku skojarzenia ze statyną. Fibraty zmniejszają stężenie TG, stężenie nie-HDL-C oraz liczbę małych gęstych LDL-C. Ponadto zwiększają stężenie HDL-C we krwi. Ich zastosowanie jest szczególnie uzasadnione u osób chorych na cukrzycę i z zespołem metabolicznym [78]. Dla fenofibratu istnieją też najpełniejsze dane dotyczące terapii kompleksowej ze statynami [79]. 
Podsumowanie - propozycja multidyscyplinarnego dekalogu „aterogennej dyslipidemii” w Polsce

1. Najbardziej reprezentatywne dane statystyczne dotyczące dorosłej populacji mieszkańców naszego kraju (NATPOL 2011) pozwalają szacować, że 10,5 mln dorosłych Polaków ma obniżone stężenie HDL-C, a u 3,2 mln stężenie TG wynosi co najmniej $200 \mathrm{mg} / \mathrm{dl}$.

2. Wysokie stężenie TG i niskie stężenie HDL-C są zarówno niezależnymi czynnikami ryzyka zdarzeń sercowo-naczyniowych, jak i elementem rozpoznania dyslipidemii aterogennej. Oprócz oceny podstawowych frakcji lipidów (stężenie LDL-C, HDL-C, TG, cholesterolu całkowitego) należy oceniać nie-HDL-C (drugorzędowy cel leczenia). Automatyczne wyliczenie stężenia nie-HDL-C powinno znajdować się w każdym rutynowym lipidogramie oznaczanym w Polsce.

3. Obowiązujące od 2016 roku wytyczne europejskie dotyczące dyslipidemii, poza celem pierwszorzędowym (osiągnięcie LDL-C $\leq 70 \mathrm{mg} / \mathrm{dl}, \leq 100 \mathrm{mg} / \mathrm{dl}$ oraz < $115 \mathrm{mg} / \mathrm{dl}$, odpowiednio, u osób: bardzo wysokiego, wysokiego oraz średniego i niskiego ryzyka sercowo-naczyniowego), wprowadziły cel drugorzędowy, w którym uznano konieczność osiągnięcia nie-HDL-C: $<100 \mathrm{mg} / \mathrm{dl}$, $<130 \mathrm{mg} /$ dl oraz < $145 \mathrm{mg} / \mathrm{dl}$ odpowiednio dla osób z grup: bardzo wysokiego, wysokiego oraz średniego ryzyka sercowo-naczyniowego.

4. Mimo że samo obniżanie stężenia TG oraz podwyższanie stężenia HDL nie jest aktualnie celem leczenia, wysokie stężenie TG i niskie stężenie HDL-C są nadal niezależnymi czynnikami ryzyka zdarzeń sercowo-naczyniowych.

5. Leczenie dyslipidemii aterogennej ma szczególne znaczenie u chorych na cukrzyce, z zespołem me- tabolicznym, otyłością, przewlekłą chorobą nerek oraz u pacjentów z wysokim stężeniem TG. Dlatego też szczególną rolę odgrywają lekarze rodzinni, interniści, diabetolodzy, nefrolodzy, kardiolodzy, hipertensjolodzy, neurolodzy i okuliści w aktywnym wyszukiwaniu pacjentów z dyslipidemią aterogenną.

6. Farmakoterapię (fenofibrat) można rozważyć u każdego pacjenta, zarówno leczonego statyną (dodanie fenofibratu), jak i nieleczonego (włączenie fenofibratu lub statyny $z$ fenofibratem), z wysokim stężeniem nie-HDL-C, podwyższonym stężeniem TG (> $200 \mathrm{mg} / \mathrm{dl}$ ), wysokim ryzykiem sercowo-naczyniowym.

7. U pacjenta z dyslipidemią aterogenną statyna w monoterapii nie zabezpiecza w pełni przed zdarzeniem sercowo-naczyniowym (ryzyko rezydualne, ryzyko resztkowe). Optymalnym sposobem leczenia chorych z dyslipidemią aterogenną obciążonych cukrzycą, zespołem metabolicznym jest więc terapia kompleksowa z zastosowaniem dowolnej statyny oraz fenofibratu. W Polsce nie są jeszcze dostępne preparaty złożone statyny i fenofibratu, ale leki takie stosowane są już na innych rynkach farmaceutycznych.

8. Na podstawie dotychczasowych badań można stwierdzić, że w Polsce w codziennej praktyce zbyt rzadko lekarze decydują się na zastosowanie terapii kompleksowej (statyna + fenofibrat) w grupie pacjentów z dyslipidemią aterogenną.

9. U chorych $z$ aterogenną dyslipidemią terapia fibratem pozwala na osiągnięcie wszechstronnej modyfikacji profilu lipidowego (zmniejszenia stężenia TG, wzrost stężenia HDL-C, zmiany fenotypu cząstek LDL) i redukuje ryzyko sercowo-naczyniowe.

10. Fenofibrat to jedyny lek z grupy fibratów, dla którego dostępne są szersze dane dotyczące stosowania w terapii kompleksowej ze statyną, a rozpowszechnienie jego stosowania powoduje, że stał się lekiem z wyboru w swojej klasie.

\section{Abstract}

Dyslipidemia is the most common risk factor for cardiovascular diseases in Poland. According to the latest guidelines of Scientific Societies, the primary goal of lipid-lowering therapy is to lower LDL-cholesterol, but we should not underestimate the impact of atherogenic dyslipidemia, defined as elevated levels of triglycerides (TG) and very-low-density lipoprotein (VLDL) and decreased HDL-cholesterol (HDL-C), on the progression of atherosclerosis. High TG and low HDL-C are independent risk factors for cardiovascular events, which can be effectively monitored and treated with statins and fenofibrate. The following consensus statement of Polish experts is an attempt to summarize the latest knowledge in the field of atherogenic dyslipidemia and to develop the recommendations for its treatment.

Key words: atherogenic dyslipidaemia, expert consensus, cardiovascular risk

Folia Cardiologica 2017; 12, 1: 33-49 


\section{Piśmiennictwo}

1. Catapano AL, Graham I, De Backer G. 2016 ESC/EAS Guidelines for the Management of Dyslipidaemias: The Task Force for the Management of Dyslipidaemias of the European Society of Cardiology (ESC) and European Atherosclerosis Society (EAS) Developed with the special contribution of the European Assocciation for Cardiovascular Prevention \& Rehabilitation (EACPR). Atherosclerosis. 2016; 253: 281-344, doi: 10.1016/j.atherosclerosis.2016.08.018, indexed in Pubmed: 27594540.

2. Piepoli MF, Hoes AW, Agewall S, et al. Authors/Task Force Members, Authors/Task Force Members, Additional Contributor: Simone Binno (Italy), Document Reviewers, Authors/Task Force Members. 2016 European Guidelines on cardiovascular disease prevention in clinical practice: the Sixth Joint Task Force of the European Society of Cardiology and Other Societies on Cardiovascular Disease Prevention in Clinical Practice (constituted by representatives of 10 societies and by invited experts)Developed with the special contribution of the European Association for Cardiovascular Prevention \& Rehabilitation (EACPR). Eur Heart J. 2016; 37(29): 2315-2381, doi: 10.1093/eurheartj/ehw106, indexed in Pubmed: 27222591.

3. Leiter LA, Lundman P, da Silva PM, et al. DYSIS investigators. Persistent lipid abnormalities in statin-treated patients with diabetes mellitus in Europe and Canada: results of the Dyslipidaemia International Study. Diabet Med. 2011; 28(11): 1343-1351, doi: 10.1111/j.14645491.2011.03360.x, indexed in Pubmed: 21679231.

4. Zdrojewski T, Solnica B, Cybulska B, et al. Prevalence of lipid abnormalities in Poland. The NATPOL 2011 survey. Kardiol Pol. 2016; 74(3): 213-223, doi: 10.5603/KP.2016.0029, indexed in Pubmed: 27004543.

5. de la Sierra A, Gorostidi M, Aranda P, et al. Prevalence of Atherogenic Dyslipidemia in Spanish Hypertensive Patients and Its Relationship With Blood Pressure Control and Silent Organ Damage. Rev Esp Cardiol (Engl Ed). 2015; 68(7): 592-598, doi: 10.1016/j.rec.2014.07.029, indexed in Pubmed: 25487323.

6. Toth PP, Barter PJ, Rosenson RS, et al. High-density lipoproteins: a consensus statement from the National Lipid Association. J Clin Lipidol. 2013; 7(5): 484-525, doi: 10.1016/j.jacl.2013.08.001, indexed in Pubmed: 24079290.

7. Robinson JG, Wang S, Smith BJ, et al. Meta-analysis of the relationship between non-high-density lipoprotein cholesterol reduction and coronary heart disease risk. J Am Coll Cardiol. 2009; 53(4): 316-322, doi: 10.1016/j.jacc.2008.10.024, indexed in Pubmed: 19161879.

8. Boekholdt SM, Arsenault BJ, Mora S, et al. Association of LDL cholesterol, non-HDL cholesterol, and apolipoprotein B levels with risk of cardiovascular events among patients treated with statins: a meta-analysis. JAMA. 2012; 307(12): 1302-1309, doi: 10.1001/ /jama.2012.366, indexed in Pubmed: 22453571.

9. Hokanson JE, Austin MA. Plasma triglyceride level is a risk factor for cardiovascular disease independent of high-density lipoprotein cholesterol level: a meta-analysis of population-based prospective studies. J Cardiovasc Risk. 1996; 3(2): 213-219, indexed in Pubmed: 8836866.

10. Faergeman 0, Holme I, Fayyad R, et al. Steering Committees of IDEAL and TNT Trials. Plasma triglycerides and cardiovascular events in the Treating to New Targets and Incremental Decrease in End-Points through Aggressive Lipid Lowering trials of statins in patients with coronary artery disease. Am J Cardiol. 2009; 104(4): 459-463, doi: 10.1016/j.amjcard.2009.04.008, indexed in Pubmed: 19660594.

11. Miller M, Cannon CP, Murphy SA, et al. PROVE IT-TIMI 22 Investigators. Impact of triglyceride levels beyond low-density lipoprotein cholesterol after acute coronary syndrome in the PROVE IT-TIMI 22 trial. J Am Coll Cardiol. 2008; 51(7): 724-730, doi: 10.1016/j.jacc.2007.10.038, indexed in Pubmed: 18279736.

12. Assmann G, Cullen P, Schulte $H$. The Münster Heart Study (PROCAM). Results of follow-up at 8 years. Eur Heart J. 1998; 19 Suppl A: A2-11, indexed in Pubmed: 9519336.

13. Barter P, Gotto AM, LaRosa JC, et al. Treating to New Targets Investigators. HDL cholesterol, very low levels of LDL cholesterol, and cardiovascular events. N Engl J Med. 2007; 357(13): 1301-1310, doi: 10.1056/NEJMoa064278, indexed in Pubmed: 17898099.

14. Retnakaran R, Cull CA, Thorne KI, et al. UKPDS Study Group. Risk factors for renal dysfunction in type 2 diabetes: U.K. Prospective Diabetes Study 74. Diabetes. 2006; 55(6): 1832-1839, doi: 10.2337/ /db05-1620, indexed in Pubmed: 16731850.

15. Colhoun HM, Betteridge DJ, Durrington PN, et al. CARDS investigators. Primary prevention of cardiovascular disease with atorvastatin in type 2 diabetes in the Collaborative Atorvastatin Diabetes Study (CARDS): multicentre randomised placebo-controlled trial. Lancet. 2004; 364(9435): 685-696, doi: 10.1016/S0140-6736(04)16895-5, indexed in Pubmed: 15325833.

16. Buse JB, Bigger JT, Byington RP. Action to Control Cardiovascular Risk in Diabetes (ACCORD) trial: design and methods. Am J Cardiol. 2007; 99(12A): 21i-31i, doi: 10.1016/j.amjcard.2007.03.003, indexed in Pubmed: 17599422.

17. Ginsberg HN, Elam MB, Lovato LC, et al. ACCORD Study Group. Effects of combination lipid therapy in type 2 diabetes mellitus. N Engl J Med. 2010; 362(17): 1563-1574, doi: 10.1056/NEJMoa1001282, indexed in Pubmed: 20228404.

18. Secondary prevention by raising HDL cholesterol and reducing triglycerides in patients with coronary artery disease: the Bezafibrate Infarction Prevention (BIP) Study. Circulation. 2000; 102(1): 21-27, doi: 10.1161/01.cir.102.1.21.

19. Arbel Y, Klempfner R, Erez A, et al. BIP Study Group. Bezafibrate for the treatment of dyslipidemia in patients with coronary artery disease: 20-year mortality follow-up of the BIP randomized control trial. Cardiovasc Diabetol. 2016; 15: 11, doi: 10.1186/s12933-016-0332-6, indexed in Pubmed: 26794137.

20. Lyons TJ, Jenkins AJ, Zheng D. Diabetic retinopathy and serum lipoprotein subclasses in the DCCT/EDIC cohort. Invest Ophthalmol Vis Sci. 2004; 45(3): 910-918, indexed in Pubmed: 14985310.

21. Keech A, Simes RJ, Barter P, et al. FIELD Study Investigators. Effects of long-term fenofibrate therapy on cardiovascular events in 9795 people with type 2 diabetes mellitus (the FIELD study) Lancet. 2005; 366: 1840-1861.

22. Ansquer JC, Foucher C, Rattier S, et al. DAIS Investigators. Fenofibrate reduces progression to microalbuminuria over 3 years in a placebo-controlled study in type 2 diabetes: results from the Diabetes Atherosclerosis Intervention Study (DAIS). Am J Kidney Dis. 2005; 45(3): 485-493, doi: 10.1053/j.ajkd.2004.11.004, indexed in Pubmed: 15754270.

23. Chew EY, Ambrosius WT, Davis MD, et al. ACCORD Study Group, ACCORD Eye Study Group. Effects of medical therapies on retinopathy progression in type 2 diabetes. N Engl J Med. 2010; 363(3): 233-244, doi: 10.1056/NEJMoa1001288, indexed in Pubmed: 20587587.

24. Catapano AL, Graham I, De Backer B, et al. ESC/EAS Guidelines for the management of dyslipidaemias: the Task Force for the management of dyslipidaemias of the European Society of Cardiology (ESC) and the European Atherosclerosis Society (EAS). Eur Heart J. 2016; 37(39): 2999-3058, doi: 10.1093/eurheartj/ehw272. 
25. Wożakowska-Kapłon B, Filipiak KJ, Mamcarz A, et al. [Actual problems of dyslipidaemia treatment in Poland $-2^{\text {nd }}$ Declaration of Sopot. Experts' Group Consensus endorsed by the Polish Cardiac Society Working Group on Cardiovascular Pharmacotherapy] [Article in Polish]. Kardiol Pol. 2014; 72(9): 847-853, doi: 10.5603/KP.2014.0182, indexed in Pubmed: 25231425.

26. Cannon CP, Blazing MA, Giugliano RP, et al. IMPROVE-IT Investigators. Ezetimibe Added to Statin Therapy after Acute Coronary Syndromes. N Engl J Med. 2015; 372(25): 2387-2397, doi: 10.1056/ /NEJMoa1410489, indexed in Pubmed: 26039521.

27. Miller M, Cannon CP, Murphy SA, et al. PROVE IT-TIMI 22 Investigators. Impact of triglyceride levels beyond low-density lipoprotein cholesterol after acute coronary syndrome in the PROVE IT-TIMI 22 trial. J Am Coll Cardiol. 2008; 51(7): 724-730, doi: 10.1016/j.jacc.2007.10.038, indexed in Pubmed: 18279736.

28. Yun KHo, Shin IS, Rhee SJ, et al. Clinical significance of on-treatment triglyceride level in patients treated by percutaneous coronary intervention for non-ST-segment elevation acute coronary syndrome. Korean J Intern Med. 2009; 24(4): 330-336, doi: 10.3904/ /Kjim.2009.24.4.330, indexed in Pubmed: 19949731.

29. Schwartz GG, Abt M, Bao W, et al. Fasting triglycerides predict recurrent ischemic events in patients with acute coronary syndrome treated with statins. J Am Coll Cardiol. 2015; 65(21): 2267-2275, doi: 10.1016/j.jacc.2015.03.544, indexed in Pubmed: 26022813.

30. Buturak A, Degirmencioglu A, Erturk M, et al. Impact of increased admission lipid levels on periprocedural myocardial injury following an elective percutaneous coronary intervention. Coron Artery Dis. 2015; 26(4): 333-340, doi: 10.1097/MCA.0000000000000235, indexed in Pubmed: 25714068.

31. Shah HD, Parikh KH, Chag MC, et al. Beneficial effects of the addition of fenofibrate to statin therapy in patients with acute coronary syndrome after percutaneous coronary interventions. Exp Clin Cardiol. 2007; 12(2): 91-96, indexed in Pubmed: 18650989.

32. Efficacy of cholesterol-lowering therapy in 18686 people with diabetes in 14 randomised trials of statins: a meta-analysis. The Lancet. 2008; 371(9607): 117-125, doi: 10.1016/s0140-6736(08)60104-x.

33. Fruchart JC, Sacks FM, Hermans MP, et al. Residual Risk Reduction Initiative (R3I). The Residual Risk Reduction Initiative: a call to action to reduce residual vascular risk in dyslipidaemic patient. Diab Vasc Dis Res. 2008; 5(4): 319-335, doi: 10.3132/dvdr.2008.046, indexed in Pubmed: 18958843.

34. Guy J, Ogden L, Wadwa RP, et al. Lipid and lipoprotein profiles in youth with and without type 1 diabetes: the SEARCH for Diabetes in Youth case-control study. Diabetes Care. 2009; 32(3): 416-420, doi: 10.2337/dc08-1775, indexed in Pubmed: 19092167.

35. Robinson JG, Wang S, Smith BJ, et al. Meta-analysis of the relationship between non-high-density lipoprotein cholesterol reduction and coronary heart disease risk. J Am Coll Cardiol. 2009; 53(4): 316-322, doi: 10.1016/j.jacc.2008.10.024, indexed in Pubmed: 19161879.

36. Jun M, Foote C, Lv J, et al. Effects of fibrates on cardiovascular outcomes: a systematic review and meta-analysis. Lancet. 2010; 375(9729): 1875-1884, doi: 10.1016/S0140-6736(10)60656-3, indexed in Pubmed: 20462635.

37. Jun M, Zhu B, Tonelli M, et al. Effects of fibrates in kidney disease: a systematic review and meta-analysis. J Am Coll Cardiol. 2012; 60(20): 2061-2071, doi: 10.1016/j.jacc.2012.07.049, indexed in Pubmed: 23083786.

38. Ginsberg HN, Elam MB, Lovato LC, et al. ACCORD Study Group. Effects of combination lipid therapy in type 2 diabetes mellitus. N Engl J Med. 2010; 362(17): 1563-1574, doi: 10.1056/NEJMoa1001282, indexed in Pubmed: 20228404.
39. Mychaleckyj JC, Craven T, Nayak U, et al. Reversibility of fenofibrate therapy-induced renal function impairment in ACCORD type 2 diabetic participants. Diabetes Care. 2012; 35(5): 1008-1014, doi: 10.2337/ /dc11-1811, indexed in Pubmed: 22432114.

40. Ting RD, Keech AC, Drury PL, et al. FIELD Study Investigators. Benefits and safety of long-term fenofibrate therapy in people with type 2 diabetes and renal impairment: the FIELD Study. Diabetes Care. 2012; 35(2): 218-225, doi: 10.2337/dc11-1109, indexed in Pubmed: 22210576.

41. Davis TM, Ting R, Best JD, et al. Effects of fenofibrate on renal function in patients with type 2 diabetes mellitus: the Fenofibrate Intervention and Event Lowering in Diabetes (FIELD) Study. Diabetologia. 2011; 54(2): 280-290, doi: 10.1007/s00125-010-1854-1, indexed in Pubmed: 20668832.

42. Udani SM, Bakris GL. Do fibrates truly preserve kidney function? Nat Rev Endocrinol. 2011; 7(3): 130-131, doi: 10.1038/nrendo.2011.14, indexed in Pubmed: 21301489.

43. Niewada M, Skowrońska M, Ryglewicz D, et al. Polish National Stroke Prevention and Treatment Collaborative Group. Acute ischemic stroke care and outcome in centers participating in the Polish National Stroke Prevention and Treatment Registry. Stroke. 2006; 37(7): 1837-1843, doi: 10.1161/01.STR.0000226992.39847.ef, indexed in Pubmed: 16741176.

44. Sacco RL, Benjamin EJ, Broderick JP, et al. American Heart Association Prevention Conference. IV. Prevention and Rehabilitation of Stroke. Risk factors. Stroke. 1997; 28(7): 1507-1517, indexed in Pubmed: 9227708.

45. González-García S, González-Quevedo A, Fernández-Concepción 0, et al. Gonzales-Quevedo Monteagudo A, Zuaznabar MAB. Association between blodd lipids and types of strokes. MEDICC Review. 2008; 10: 27-32.

46. Iso $H$, Jacobs DR, Wentworth D, et al. Serum cholesterol levels and six-year mortality from stroke in 350,977 men screened for the multiple risk factor intervention trial. N Engl J Med. 1989; 320(14): 904-910, doi: 10.1056/NEJM198904063201405, indexed in Pubmed: 2619783.

47. Collins R, Armitage J, Parish S, et al. Heart Protection Study Collaborative Group. Effects of cholesterol-lowering with simvastatin on stroke and other major vascular events in 20536 people with cerebrovascular disease or other high-risk conditions. Lancet. 2004; 363(9411): 757-767, doi: 10.1016/S0140-6736(04)15690-0, indexed in Pubmed: 15016485.

48. Amarenco P, Bogousslavsky J, Callahan A, et al. Stroke Prevention by Aggressive Reduction in Cholesterol Levels (SPARCL) Investigators. High-dose atorvastatin after stroke or transient ischemic attack. N Engl J Med. 2006; 355(6): 549-559, doi: 10.1056/ /NEJMoa061894, indexed in Pubmed: 16899775.

49. Amarenco P, Labreuche J, Lavallée P, et al. Statins in stroke prevention and carotid atherosclerosis: systematic review and up-to-date meta-analysis. Stroke. 2004; 35(12): 2902-2909, doi: 10.1161/01. STR.0000147965.52712.fa, indexed in Pubmed: 15514180.

50. O'Donnell MJ, Chin SL, Rangarajan S, et al. INTERSTROKE investigators, INTERSTROKE investigators. Risk factors for ischaemic and intracerebral haemorrhagic stroke in 22 countries (the INTERSTROKE study): a case-control study. Lancet. 2010; 376(9735): 112-123, doi: 10.1016/ /S0140-6736(10)60834-3, indexed in Pubmed: 20561675.

51. Sacco RL, Benson RT, Kargman DE, et al. High-density lipoprotein cholesterol and ischemic stroke in the elderly: the Northern Manhattan Stroke Study. JAMA. 2001; 285(21): 2729-2735, indexed in Pubmed: 11386928.

52. Pikula A, Beiser AS, Wang J, et al. Lipid and lipoprotein measurements and the risk of ischemic vascular events: Framingham Study. Neurolo- 
gy. 2015; 84(5): 472-479, doi: 10.1212/WNL.0000000000001202, indexed in Pubmed: 25568296.

53. Zhu S, Su G, Meng QH. Inhibitory effects of micronized fenofibrate on carotid atherosclerosis in patients with essential hypertension. Clin Chem. 2006; 52(11): 2036-2042, doi: 10.1373/ /clinchem.2006.074724, indexed in Pubmed: 16990410.

54. Schwartz GG, Abt M, Bao W, et al. Fasting triglycerides predict recurrent ischemic events in patients with acute coronary syndrome treated with statins. J Am Coll Cardiol. 2015; 65(21): 2267-2275, doi: 10.1016/j.jacc.2015.03.544, indexed in Pubmed: 26022813.

55. Alpérovitch $\mathrm{A}$, Kurth $\mathrm{T}$, Bertrand $\mathrm{M}$, et al. Primary prevention with lipid lowering drugs and long term risk of vascular events in older people: population based cohort study. BMJ. 2015; 350: h2335, indexed in Pubmed: 25989805.

56. Ouk T, Gautier S, Pétrault M, et al. Effects of the PPAR- $\alpha$ agonist fenofibrate on acute and short-term consequences of brain ischemia. J Cereb Blood Flow Metab. 2014; 34(3): 542-551, doi: 10.1038/ /jcbfm.2013.233, indexed in Pubmed: 24398933.

57. Zhou YH, Ye XF, Yu FF, et al. Lipid management in the prevention of stroke: a meta-analysis of fibrates for stroke prevention. BMC Neurol. 2013; 13: 1, doi: 10.1186/1471-2377-13-1, indexed in Pubmed: 23282097.

58. Wang D, Liu B, Tao W, et al. Fibrates for secondary prevention of cardiovascular disease and stroke. Cochrane Database Syst Rev. 2015(10): CD009580, doi: 10.1002/14651858.CD009580.pub2, indexed in Pubmed: 26497361.

59. Davis TME, Yeap BB, Davis WA, et al. Lipid-lowering therapy and peripheral sensory neuropathy in type 2 diabetes: the Fremantle Diabetes Study. Diabetologia. 2008; 51(4): 562-566, doi: 10.1007/ /s00125-007-0919-2, indexed in Pubmed: 18193189.

60. Cho YeR, Lim JiH, Kim MY, et al. Therapeutic effects of fenofibrate on diabetic peripheral neuropathy by improving endothelial and neural survival in db/db mice. PLoS One. 2014; 9(1): e83204, doi: 10.1371/ /journal.pone.0083204, indexed in Pubmed: 24392081.

61. Othman A, Benghozi R, Alecu I, et al. Fenofibrate lowers atypical sphingolipids in plasma of dyslipidemic patients: A novel approach for treating diabetic neuropathy? J Clin Lipidol. 2015; 9(4): 568-575, doi: 10.1016/j.jacl.2015.03.011, indexed in Pubmed: 26228675.

62. Tight blood pressure control and risk of macrovascular and microvascular complications in type 2 diabetes: UKPDS 38. UK Prospective Diabetes Study Group. BMJ. 1998; 317(7160): 703-713, indexed in Pubmed: 9732337.

63. Scott R, O'Brien R, Fulcher G, et al. Fenofibrate Intervention and Event Lowering in Diabetes (FIELD) Study Investigators. Effects of fenofibrate treatment on cardiovascular disease risk in 9,795 individuals with type 2 diabetes and various components of the metabolic syndrome: the Fenofibrate Intervention and Event Lowering in Diabetes (FIELD) study. Diabetes Care. 2009; 32(3): 493-498, doi: 10.2337/dc081543, indexed in Pubmed: 18984774.

64. Ginsberg HN, Elam MB, Lovato LC, et al. ACCORD Study Group. Effects of combination lipid therapy in type 2 diabetes mellitus. N Engl J Med. 2010; 362(17): 1563-1574, doi: 10.1056/NEJMoa1001282, indexed in Pubmed: 20228404.

65. Stanowisko Polskiego Towarzystwa Diabetologicznego „Zalecenia kliniczne dotyczące postępowania u chorych na cukrzycę 2016". Diabetol Klin. 2016; 5(supl. A): A1-A76.

66. Li W, Yanoff M, Liu X, et al. Retinal capillary pericyte apoptosis in early human diabetic retinopathy. Chin Med J (Engl). 1997; 110(9): 659-663, indexed in Pubmed: 9642318.
67. Ejaz S, Chekarova I, Ejaz A, et al. Importance of pericytes and mechanisms of pericyte loss during diabetes retinopathy. Diabetes Obes Metab. 2008; 10(1): 53-63, doi: 10.1111/j.1463-1326.2007.00795.x, indexed in Pubmed: 17941874.

68. Ding J, Wong TY. Current epidemiology of diabetic retinopathy and diabetic macular edema. Curr Diab Rep. 2012; 12(4): 346-354, doi: 10.1007/s11892-012-0283-6, indexed in Pubmed: 22585044.

69. Klein BE. Overview of epidemiologic studies of diabetic retinopathy. Ophthalmic Epidemiol. 2007; 14(4): 179-183, doi: 10.1080/ /09286580701396720, indexed in Pubmed: 17896294.

70. King P, Peacock I, Donnelly R. The UK prospective diabetes study (UKPDS): clinical and therapeutic implications for type 2 diabetes. $\mathrm{Br} \mathrm{J}$ Clin Pharmacol. 1999; 48(5): 643-648, indexed in Pubmed: 10594464.

71. The effect of intensive treatment of diabetes on the development and progression of long-term complications in insulin-dependent diabetes mellitus. The Diabetes Control and Complications Trial Research Group. N Engl J Med. 1993; 329(14): 977-986, doi: 10.1056/ /NEJM199309303291401, indexed in Pubmed: 8366922.

72. Schrier RW, Estacio RO, Mehler PS, et al. Appropriate blood pressure control in hypertensive and normotensive type 2 diabetes mellitus: a summary of the ABCD trial. Nat Clin Pract Nephrol. 2007; 3(8): 428-438, doi: 10.1038/ncpneph0559, indexed in Pubmed: 17653121.

73. Bosomworth NJ. Approach to identifying and managing atherogenic dyslipidemia: a metabolic consequence of obesity and diabetes. Can Fam Physician. 2013; 59(11): 1169-1180, indexed in Pubmed: 24235189.

74. Chew EY, Ambrosius WT, Davis MD, et al. ACCORD Study Group, ACCORD Eye Study Group. Effects of medical therapies on retinopathy progression in type 2 diabetes. N Engl J Med. 2010; 363(3): 233-244, doi: 10.1056/NEJMoa1001288, indexed in Pubmed: 20587587.

75. Noonan JE, Jenkins AJ, Ma JX, et al. An update on the molecular actions of fenofibrate and its clinical effects on diabetic retinopathy and other microvascular end points in patients with diabetes. Diabetes. 2013; 62(12): 3968-3975, doi: 10.2337/db13-0800, indexed in Pubmed: 24264394.

76. Stanowisko Polskiego Towarzystwa Diabetologicznego „Zalecenia kliniczne dotyczące postępowania u chorych na cukrzycę 2016". Diabetol Klin. 2016; 5(supl. A): A1-A76.

77. Rydén L, Grant PJ, Anker SD, et al. Authors/Task Force Members, ESC Committee for Practice Guidelines (CPG), Document Reviewers. ESC Guidelines on diabetes, pre-diabetes, and cardiovascular diseases developed in collaboration with the EASD: the Task Force on diabetes, pre-diabetes, and cardiovascular diseases of the European Society of Cardiology (ESC) and developed in collaboration with the European Association for the Study of Diabetes (EASD). Eur Heart J. 2013; 34(39): 3035-3087, doi: 10.1093/eurhearti/eht108, indexed in Pubmed: 23996285.

78. Wożakowska-Kapłon B, Filipiak K, Mamcarz A, et al. [Actual problems of dyslipidaemia treatment in Poland - 2nd Declaration of Sopot. Experts' Group Consensus endorsed by the Polish Cardiac Society Working Group on Cardiovascular Pharmacotherapy]. [Article in Polish]. Kardiol Pol. 2014; 72(9): 847-853, doi: 10.5603/kp.2014.0182, indexed in Pubmed: 25231425.

79. Aguiar C, Alegria E, Bonadonna RC, et al. A review of the evidence on reducing macrovascular risk in patients with atherogenic dyslipidaemia: A report from an expert consensus meeting on the role of fenofibrate-statin combination therapy. Atheroscler Suppl. 2015; 19: 1-12, doi: 10.1016/S1567-5688(15)30001-5, indexed in Pubmed: 26315511. 